"Is All the World a Text?

Prom Social History to the History

of Society Two Decades Later

$$
\text { Geoff Eley }
$$

$\begin{array}{llr}\text { CSST Working } & \text { CRSo Working } \\ \text { Paper \#55 } & \text { Paper \#445 }\end{array}$


"IS ALL THE WORLD A TEXT? FROM SOCIAL HISTORY TO THE HISTORY OF SOCIETY TWO DECADES LATER".

\author{
GEOFF ELEY \\ DEPARTMENT OF HISTORY \\ UNIVERSITY OF MICHIGAN
}

"History to the defeated may say Alas but cannot help or pardon".

\author{
W. H. Auden
}

"There is no document of civilization that is not simultaneously a record of barbarism".

Walter Benjamin

"History will teach us nothing". 
In The Beginning

In 1971 Eric Hobsbawm called it "a good moment to be a social historian". [1] Ten years later this was still the case, despite a certain fractiousness and the readiness of some to find a crisis of: the field. The main thing was the continuing growth of activity (the proliferation of journals, conferences, sub-disciplinary: societies, international networks, curricular initiatives, and dissertations, despite the contraction of history graduate programs), and in light of such expansion conflicts of direction were perhaps the normal signs of diversification and growth. That social historians could argue over theory and: method was evidence of vitality more than ill-health, and only those with narrow or sectarian views of social history's proper orientation could be upset by conflict as such. [2]

Ten years further on still, though, such confidence is harder to sustain. I am not the oniy:person to have detected a general discursive shift in the rhetoric and practice of the profession from "social" to "cultural" history, effected via what we have become accustomed to.: call the "linguistic turn". Clearly this observation: needs to. be elaborated and specified, but a good barometer of the change in historiographical sensibility has been Gareth Stedman Jones. From his invigorating polemic against the liberal complacencies: and positivistic assumptions of the British historiographical tradition in 1967 to a variety of.critical: and substantive essays in the mid-1970s, Stedman Jones developed a project of "non-empiricist" and "theoretically informed history", which was Marxist, open to other forms of social theory, and naturally materialist, as the unifying problematic of contemporary social history: then took that: to be understood. For many social historians, therefore, it was very disconcerting when in 1983 Stedman Jones seemed to embrace a form of linguistic analysis that was decidedly non-materialist in the classical sense and seemed to call the given assumptions of social history into doubt. Moreover, since that time things have moved fast. Stedman Jones' own rather cautious formulations have been left behind, disappearing in a more radical polarity of so-called "deconstructionists" and unrepentant materialists. [3] of course, the social history: that emerged from the 1960 s was never a unitary project. But some notion of social determination, conceptualized on the ground of material life, whether in demographic, political-economic, labor-process, class-sociological or class-cultural terms, generally provided a tissue of common assumptions. From a vantage-point at the end of the 1980s, by contrast, a rough division seems to have opened within this "broad church", between those who: have been rethinking their assumptions to the point of radically subverting the determinative coherence of the category of the social, and those who continue defending: the particular social-history materialism that: formed them.

In this respect, social history has become one site of a general epistemological uncertainty, which characterizes large areas of academic-intellectual life in the humanities and social sciences in the late-twentieth century. This flux is perhaps more extensive in, say, Britain and France than in,. say, Germany and the USA (in the sense that it pervades more disciplines more completely), and more central. to disciplinary discussion in, say, literature and anthropology than in, say, sociology and the "harder" social sciences. Not by accident, the most radical: and influential discussions have been occurring in areas which lack the constraining power of disciplinary. traditions--especially women's studies and the emerging field of cultural studies. A valuable map of this uncertainty is provided by Peter Novick's concluding chapters in That Noble Dream, which usefully remind us of its more-than-french origins, building his account 
around Kuhn, Rorty, Fish and Geertz rather than Foucault, Lacan, Barthes and Derrida. But Novick also assimilates the debates too easily to the binary framework of "objectivism"/"relativism". While he is undoubtedly correct to find the dissolution during the last three decades of "History" as a professionally centered disciplinary project, he focuses too heavily on the ever-more elaborate process of academic specialization and understates the impact of "contemporary continental thought". In fact, so far from having "little positive resonance within the historical profession, and practically none outside the sub-discipline of European intellectual history", figures like Hayden White and Dominick LaCapra have become the advance guard of a much broader intellectual phenomenon. By 1990, I would argue, interest in Foucault and Derrida extends far beyond a few "professionally marginal historians whose primary allegiance was to interdisciplinary communities with a membership made up largely of literary theorists, cultural critics, and philosophers". [4]

Periodizing this movement is difficult with any precision. In retrospect, the first wave of polemical stock-taking essays, which are usually cited as marking a "crisis" of social history in the second half of the 1970s--those by Fox-Genovese and Genovese, Stedman Jones, Stone, and Judt--were indeed remarkably innocent of the post-structuralist theory whose absence Novick detects in the discourse of historians, and mostly stood their ground on an extremely unproblematic kind of materialism. We could make a similar point from a variety of other programmatic statements--including the founding editorials of new journals like Social History (SH) and History Workshop Journal (HWJ), both launched in 1976, or the omnibus survey of US historical writing edited by Michael Kammen for the AHA, The Past Before Us (Ithaca and London, 1980), whose essays were commissioned in 1977-78 in an intellectual conjuncture also defined by the mid-1970s. In other words, this earlier moment of stock-taking belongs far more to the period of social history's dramatic post-sixties expansion than to the current period of uncertainty and flux--proceeding on the basis of the former's materialist assumptions rather than bringing them into doubt. Moreover, a systematic survey of more established social history journals--like Past and Present (P\&P), Journal of Interdisciplinary History (JIH), or Journal of Social History (JSH), let alone more mainstream journals that also carry social history writings, like Journal of Modern History (JMH) or American Historical Review (AHR)--would also, I suspect, show a similar lack of interest in literary or linguistic theoretical influences; and whereas AHR and JMH have begun noticing the latter via review essays and forums, the older social history journals have kept their distance right down to the present, as too has another journal that was very much in the vanguard of the exchange in the 1960 s between history and social science, Comparative Studies in Society and History (CSSH). [5]

My own sense is that things began to change around 1980; and that the shift could be usefully traced through the newer journals like HWJ, SH, and Radical History Review. For instance: one might juxtapose the original editorials of HWJ on "Feminist History" and "Sociology and History" (1, Spring 1976, 4-8) and another early one on "British Economic History and the Question of Work" (3, Spring 1977, 1-4), which are.firmly continuous with the critical materialist departures of the 1960s (and still connected to the older influences of Edward Thompson, Eric Hobsbawm et al.), with the editorial on "Language and History" several years later (10, Autumn 1980, 1-5), which marked some distance from this:founding materialism. The trajectory could then be further described: HWJ's renaming as a "Journal of Socialist and Feminist Historians", 
and simultaneous publishing of a guide to "Foucault for Historians" by Jeffrey Weeks (14, Autumn 1982, 1, 106-19); an editorial on "Culture and Gender" (15, Spring 1983, 1-3); the arrival of the new feminist literary criticism in review essays by Mary Poovey and Joan Scott (22, Autumn 1986, 185-92); the gradual entry of psychoanalysis, through essays by Sally Alexander (17, Spring 1984, 125-49), Laura Mulvey and T. G. Ashplant (23, Spring 1987, 1-19 and 165-73), and then a full-blown special feature of four articles on "Psychanalysis and History" (26, Autumn 1988, 105-52), with a follow-up response by Jacqueline Rose (28, Autumn 1989, 148-54); another special feature on "Language and History", including a very severe article by Peter Schöttler on "Historians and Discourse Analysis" (27, Spring 1989, 1-65); and most recently, a special feature on the French Revolution which is heavily "culturalist" in the current literary-cum-linguistic sense (28, Autumn 1989, 1-87). [6]

To a great extent, I want to argue, this reflects a process of complex generationally-internal revision. The launching of journals like HWJ, SH, and RHR, and the strengthening and refurbishing of others, like International Labor and Working-Class History (ILWCH), marked the arrival of a particular generation (that trained in the 1960s and early 1970s) and their claiming of a distinct institutional space under the sign of a restlessly aggrandising social history. The turn to linguistically conceived forms of cultural history by the end of the 1970s, moved by a combination of changing political contexts and autonomous theoretical engagement, most sharply registered in feminism and women's history, marked the fracturing of the:same broad generational: consensus. To some extent, these tensions expressed themselves in early conflicts over theory per se, as in the acrimonious attacks on "structuralist Marxism" which dominated left-intellectual life in Britain for much of the later 1970s. [7] Moreover, the salience of this particular generation and its disagreements was magnified by the drastic reduction in the number of graduate historians in the later 1970s and early 1980s. Mainly for that reason, the succeeding generation has had little opportunity to declare its own distinctive voice--by contrast (one might guess) with the one qualifying in the later 1980s and early 1990s, which will have a great deal to say in the areas of gender history: and cultural studies.

My choice of a particular moment to dramatize this generational flux would be an intense day-long discussion held at the University of Michigan around the theme "Whence and Whither Social History?" in October 1979. I choose this occasion partly for its localiresonance, and partly for personal reasons, because it marked my own introduction to social history discussions in North America. [8] But it also nicely encapsulated the dilemmas--and incipient dispersal--of a generational cohort previously united by certain shared assumptions about the methodological and substantive purposes of the social-historical project. Convened by Louise and Charles Tilly to take advantage of the local presence of various participants in the first North American Labor History Conference at Wayne State University, it brought together a number of representative and influential voices, including James Cronin, David Levine, John Merriman, Joan Scott, William Sewell, and Edward Shorter. Organized into three consecutive sessions, the meeting was invited to address precisely the four stock-taking essays referred to above (Fox-Genovese and Genovese, Stedman Junes, Stone, and Judt), although it quickly became clear that much of the momentum came from (justified) ire at the personal polemics of: Tony Judt. As the day went on, there was much talk of the insufficiencies of "vulgar Marxism", by which seemed to be meant the quantitative study of everyday experience and material life, and the need instead for a "more sophisticated kind of cultural history". 
There was also much reference to European theory and British theoretical debate (which, as it happened, was about to reach one particularly unpleasant and chastening climax several weeks later at the thirteenth History Workshop in Ruskin College, Oxford, in December 1979). Such reference was focused partly on the interventions of the anthropologists present (Michael Taussig and Bernard Cohn), and partly on those of the present writer; and while:the theory concemed was generally taken to be Marxist or Marxist-Feminist; it was actually the imprint of a partially digested and still-emerging anti-reductionist critique, which over the longer term was in the process of dissolving the Marxist problematic as we then knew it. Finally, although the discussions had been generally conducted in a spirit of openness and generosity, with much constructive positioning and clarification, the day ended with an angry intervention by Charles Tilly (directed against certain statements by William Sewell), in which he reasserted in no uncertain terms the primacy of "the harder-edged sociological work" the conference had apparently been called to defend. [9] Important things were clearly at stake.

Looking back, this was an extremely pregnant occasion. Within the year William Sewell's Work and Revolution in France (Cambridge, 1980) had appeared; Joan Scott had moved to Brown where:she begania systematic post-structuralist encounter; and Charles Tilly continued to hold the line. Just to mention these names is to register the change--attached to Tilly in the 1960s, the former under an SSRC Training Fellowship, Scott and Sewell were probably the leading progeny in European history of the sixties union of history and sociology, but were now arguing that the new social history was itself not enough. The discourse of social historians was beginning to disobey, outgrowing the present disciplinary containers, and spilling across the boundaries its practitioners had thought secure. As Couvares said in his written statement for the Tiliy. symposium (with a curious choice of language): "The new harlots of cultural anthropology, 'thick description', and semiotics threaten daily to shift the focus, to alter the terms of the discourse". [10] Yet the documentary trace of the occasion betrays virtually nothing of this emerging intellectual history. Thus Charles Tilly notes the challenger:of "anthropological work,... the study of mentalités, and...more rigorous marxist analyses", but then seems to believe that the existing project--"collective biography, quantification, social-scientific approaches, and rigorous studies of everyday behavior"--could continue much as before. The trick was simply connecting it better to "the established historical agenda" in.llanguage other historians could understand. As far as it goes, Tilly's description of social history's "two callings" is unexceptionable:
"asking how the world we live in came into being, and how its coming into being affected the everyday lives of ordinary people; asking what could have happened to everyday experience at major historical choice points, and then inquiring how and why the outcomes won out over other possibilities". [11]

But so long as the cultural construction of: these processes is ignored (and categories such as "everyday experience" and "ordinary people" not put into question), the formulation will continue to dissatisfy. Similarly, Louise Tilly's problematizing of "work" ("to talk about changes in women's work over time, more rigorous definitions, words, categories are needed") and "politics" ("Politics must be reconceptualized so we can talk about the politics of those without formal rights") as such is all to the good. [12] But it also clear that the reconceptualizing is to proceed on a particular sociological ground. 
In that sense, Women, Work, and Family (New York, 1978) and Gender and the Politics of History (New York, 1988) are separated by far more than a matter of years. [13]

So we have entered "new times". What is striking to me, in this conjuncture, is the degree to which historians have been willing to become their: own theoreticians. This seems to me not to have been as true of the 1960s, when social history. declared its presence via a more eclectic and dependent turn to sociology (and sometimes anthropology), and the most self-conscious appropriations of social science focused on methodology (as in demography, family history, mobility studies, urban history, and so on) rather than theory per se. To that extent, Stedman Jones' essays of 1967-76, which called on historians to emancipate themselves from a junior relationship to social science and begin producing theory of their own, bespoke an accurate reading of the relationship. [14] In the meantime, in fact, some historians have been taking Stedman Jones at his word. In the 1970 s this happened partly through a return to Marx, both directly via Capital, the Grundrisse, or political writings like The Eighteenth Brumaire, and indirectly via appropriation of heterodox theorists like Gramsci. It also happened through more self-conscious critiques of historians' sociological usage, by locating particular concepts (like "social control" or "community") in their originating problematic and unpacking the accumulated meanings that might compromise their present use. [15] A turning to anthropology rather than sociology (one of the specific bugbears of the Tillys) was certainly part of this overall process; one that was already visible in the rethinking that produced Sewell's Work and Revolution in France and became the more important as anthropology itself became "historicized" during the 1980s. [16] But the most salient sites of: such independent theorizing, I would argue, are ones where uncritical borrowing is harder because of the absence of an existing practice to rationalize, as well as the paucity of relevant theory to use--where innovation, initiative, and interdisciplinarity have been inscribed more centrally in the very conditions and processes of knowledge-production, one might say--namely, the new and "un-disciplined" fields of feminist theory/women's history and cultural studies. Of course, no theory is ever conjured out of nothing, and it might be objected that historians in these latter areas are no less dependent on external theory than their predecessors (or previous incarnations) as new social historians; it is simply a different kind of theory, literary rather than social-scientific, in play. But it is no accident that several of the key influences in this domain, such as Michel Foucault or Stuart Hall, are distinguished precisely by their disobedience of conventional disciplinary classification (was Foucault a historian, or what?). And it does seem to me that historians (Joan Scott and Richard Johnson would be perfect respective examples) have become far more active participants in this new theoretical conversation than in the old. [17]

Despite Peter Novick's scepticism, therefore, there is some evidence that historians at large have been fruitfully interacting with the rich recent tradition of French post-structuralist theory and its British-American interpreters. It is significant that this reception has recently extended beyond the pages of journals like HWJ and RHR to the central organs of the North American profession: in different ways both $A H \bar{R}$ and $\mathrm{JMH}$ have given generous space to the developing debates around the impact of the "linguistic turn". [18] To an extent, this exposure has featured the disagreements of intellectual historians, that is, those most immediately concerned with language and textuality in the stronger formal sense. But there is no doubt that the ideas are now circulating far more extensively, influencing the intellectual practice and certainly the 
rhetoric of large areas of social and political history. Thus the modern German field (to cite one more example) has not been distinguished by its methodological and theoretical radicalism during the last three decades; even though there may have been groups of radicals within it, and one notable attempt to break through the conservatism with an ambitious theoretical argument about the collapse of the Weimar Republic was quickly silenced. [19] The "official" organ of North American Germanists, Central European History (CEH), has been a useful outlet for monographic and field-specific research, but has seldom surpassed a reliable middle-of-the-road solidity: apart from a couple of reviews and perhaps a couple of articles, there were no articles of an explicitly Marxist orientation until the publication of the Feldman-Abraham exchange in the seventeenth year of the journal's existence, and then the purpose was to delegitimize it; apart from a now-classic article by Renate Bridenthal in 1973 and three other articles dealing empirically with women, there were no articles with an explicitly feminist orientation until the journal's sixteenth year, when there were two, by Jean Quataert and Deborah Hertz (in the intervening five years there has been only one other, by Quataert again); even under the most generous definition, the journal's social history content has averaged at around one article.a year during the first twenty years (1967-87). [20] But in the meantime the ground has been shifting beneath the feet. The existence of the German Women's History Study Group on the east coast since the 1970s has been one sign of this, culminating in a conference at Rutgers in April 1986 on "The Meaning of Gender in German History", which sought to disturb and reshape the general thinking of the field. By the end of the decade the linguistic turn had also arrived. A conference on "Re-evaluating the Third Reich" at University of Pennsylvania in April 1988 managed to keep such influences at bay, but by $1989-90$ a series of events registered the change: a small symposium in Chicago in October 1989 on interdisciplinary influences on German history ("Postmodern Challenges in Theory and Methodology"); a major stock-taking conference on the Kaiserreich at University of Pennsylvania in February 1990, which was organized to a great extent round questions of gender and the implications of the linguistic turn; another major conference in Toronto in April on "Elections, Mass Politics, and Social Change", where much of the same discussion continued; and a big event at UCLA in April on representations of Nazism and the "Final Solution" ("On the Limits of Historical and Artistic Representation"), at which Derrida arrived personally in German history. In fact, $\mathrm{CEH}$ will be relaunched in the 1990 s by a special issue containing the position papers from the Chicago symposium. [21]

\section{The Current Landscape}

In his 1971 essay, Hobsbawm suggested that most interesting social history was clustered around six complexes of questions:

"(1) Demography and Kinship

(2) Urban studies in so far as these fall within our field

(3) Classes and social groups

(4) The history of 'mentalities' or collective consciousness or of 'culture' in the anthropologists' sense

(5) The transformation of societies (for example, modernization or industrialization)

(6) Social movements and phenomena of social protest." [22]

In reviewing this list two decades later, it's hard simply to add to the topical inventory because (as I'm arguing) the main change is an underlying shift of 
perspective rather: than the opening up of new areas. [23] The first three of Hobsbawm's categories are clearly alive and well. Thus the machinery of historical demography continues to grind out its findings, often with the barest relationship to broader questions, but at its best with a meticulous grounding in the classical materialist problematic of social change, usually from an eclectically sociological perspective. [24] Likewise, while theoretically urban history remains too loose and ill-defined a category, the urban community study has become the main practical medium for investigating class formation. [25] The historiography of class has also unfolded to a great extent within parameters outlined by Hobsbawm, and to the research on the. working class may now be added a burgeoning literature on peasants and a more recently developing one on the bourgeoisie and the petty bourgeoisie/lower middle class. [26] But as a descriptive framework for "the actual practice of social history", Hobsbawm's list no longer serves. This is partly because new topical clusters need to be added--recent growth areas of social history include crime and punishment, medicine and public health, sexuality, popular religion, work, and popular memory, while social policy and education are older ones perhaps oddly missing from Hobsbawm's original list. More to the point, though, the entire construction of social history as a (sub)disciplinary field has been shifting during the last decade, so that a body of discussion has developed parallel to the existing research, in a way which calls into question the conventionally constituted social-historical knowledge, with profound implications for all six of Hobsbawm's categories. Rather than just elaborating a longer inventory of topics, therefore, it is important to mention certain aspects of the surrounding flux.

(a) First, it needs to be said straight away that gender theory is transforming the basis on which we think about history. Whether as a dimension of analysis or an area of empirical work; women's history is absent from Hobsbawm's account, and to read older accounts such as this is to be reminded of how radical the change has been since the 1960s. [27] However, we shouldn't exaggerate the rapidity of that change. The four critiques referred to earlier in this essay (Fox-Genovese and Genovese, Stedman Jones, Stone, Judt) are almost as indifferent to the transformative consequences of the new women's history, and indeed it was not until the later 1970s that a substantial body of monographic literature started to appear. Even then, quite aside from the political process of surmounting the prejudices inscribed in the structures of the profession and its disciplinary regime, much of the new work was somewhat self-neutralizing in its effects, either by its adoption of a "separate-spheres" type of framework, or by subsuming women within the history of the family. This is true par excllence of Carl Degler's essay in The Past Before Us, but something of the same syndrome also befalls Tilly and Scott's Women, Work, and Family. [28] While this move remains controversial, it is only more recently, with the conceptual shift from the history of women to the historical construction of sexual difference, that the protected central spaces of the discipline have started to give way. Of course, a large amount of work is being done on sexual representations as such. But major areas like the history of work [29], class formation [30], citizenship and the public sphere [31], and the study of popular culture [32] are all being reshaped by the application of a gender perspective. The latter also promises to recast understandings of nationalism and fascism, although some of the emerging work on masculinity tends to settle too easily into the study of men alone rather than in their relations with women. [33] We shouldn't paint too optimistic a picture, of course. For instance, the core of historical demographers and historians of the family have remained remarkably resilient in their defence of an older-defined project. [34] But the insistent pressure 
for recognition of gender as a "useful category of historical analysis" is only likely to become more intense. [35]

(b) It is important to note the now-pervasive influence of Foucault. It would be a mistake to exaggerate retrospectively the instigating centrality of Foucault's ideas to the departures we are discussing, and in practice they have achieved their resonance only within the broader universe of thinking I will be discussing below. Again, nor can the speed of his reception be overstated. The works themselves were actually available in translation quite early. But Foucault was completely absent from the pioneering works in the social history of crime, the law, and imprisonment in the 1970s, and at that time his English-language reception was conducted around the margins of official academic life--in journals like Telos and Partisan Review in the USA, by a self-conscious avant-garde of post-new-left journals like Economy and Society, Radical Philosophy, Ideology and Consciousness, and $\mathrm{m} / \mathrm{f}$, in Britain. [36] It was only by the early-1980s that historians were explicitly beginning to take note. [37] Since that time, work on sexuality (particularly the late nineteenth and twentieth-century constructions of sexual categories), on prisons, hospitals, asylums and other institutions of confinement, on social policy and public health, and on the history of science and the academic disciplines, has been shot through with Foucault's formative influence. [38] Moreover, aside from directing attention in this way to new areas of research, Foucault's reception has had some vital theoretical effects. It has fundamentally redirected the understanding of power away from conventional institutionally-centered conceptions of government and the state,. and from the allied sociological conceptions of class domination, towards a dispersed and decentered conception of power and its "microphysics". It has sensitized us to the subtle and complex forms of the inter-relationship between power and knowledge, particularly in the latter's forms of disciplinary and administrative organization. It has delivered the extraordinarily fruitful concept of discourse as a way of theorizing both the internal rules and regularities of particular fields of knowledge (their "regimes of truth") and the more general structures of ideas and assumptions which delimit what can and cannot be thought and said in particular contexts of time and place. It has radically challenged the historian's conventional assumptions about individual and collective agency and their bases of interest and rationality, forcing us to see how instead subjectivities are constructed and produced within and through languages: of identification that lie beyond the volition and control of individuals in the classical enlightenment sense.

(c) For much of the 1970s the history of mentalites functioned as a new panacea for considerable numbers of social historians. It seemed a compelling alternative to the high-cultural, canonical, and formalistic-exegetical kind of intellectual history; it promised access to popular culture in the past; it provided ground for the application of quantitative methods and the appropriation of anthropology; and, of course, it was animated by the enticing vision of a "total history". For a while the translation and reception of the major Annales works, orchestrated by a few well-placed individuals, was virtually uncritical; as one of them said, "social history seemed to turn around the Past and Present-Annales axis and to be sweeping everything before it". [39] However, for some years the history of mentalities seems to have been in recession. The tone of the symposium which inaugurated the journal Review in 1978 was still largely celebratory, but by the mid-1980s a series of searching critiques had appeared--Stuart Clark in Past and Present, Samuel Kinser in AHR, Gregor McLennan in Marxism and the Methodologies of History, Michael Gismondi in SH, more ambiguously Patrick Hutton in History and Theory, and finally Roger Chartier 
and Dominick LaCapra in the contexts of (largely successful) attempts to reaffirm the importance of a more textually based form of. intellectual history. [40] There can be no doubt that these critiques have exposed the reductionisms and unspecified determinisms at the heart of Braudel's and Ladurie's work, together with the general unwillingness of the Annalistes to theorize their understanding of culture.- Likewise, the meticulous critiques by Chartier and LaCapra leave little doubt that intellectual history has recovered the ground it seemed to have ceded in the 1970s. Neither of these developments compromise the achievements of Marc Bloch and Lucien Febvre or preclude the continuing production: of cultural history in an Annales mode; suitably rethought in light of the discussions so initiated. [41] But this has yet to happen. On the whole historians' discussions of culture have moved elsewhere, either outside the main early modern location of Annales-influenced history, or onto the ground of language where the running is being made by feminist theorists and intellectual historians, either untouched by the Annales paradigm or directly critical of it. [42] Moreover, the more interesting uses of Bakhtin are tending to come not from social historians such as Natalie Davis and Bob Scribner, who set the pace in the 1960s and 1970s, but from literary critics. [43] In retrospect the triumphal codification of Annales achievement, La Nouvelle Histoire (Paris, 1978), now looks more like its epitaph, certainly in the history of mentalities as we encounter that in the previous decades. André Burguière's discussion, which implies the past tense, seem tacitly to recognize this. [44]

(d). Another body of cultural analysis, contemporary cultural studies, has produced relatively little historical work so far. A still-emergent crossdisciplinary formation, cultural studies comprises a varying miscellany of influences--sociologists, literary scholars, and historians in Britain (but not anthropologists), mass communications, literary theory, and potentially reflexive anthropology in the USA. Strong existing traditions (e.g. in critical enthnography, cultural anthropology, and ethnomethodology) have worked pre-emptively against cultural studies in the social sciences in the USA, outside departments of communications, while their relative weakness in Britain allowed greater corresponding space for cultural studies to emerge. Thus so far the main US initiatives have come more from the humanities (e.g. the: Unit for Criticism and Interpretive Theory at Urbana, or the Program in Comparative Studies in Discourse and Society at Minnesota), whereas the proliferating interdisciplinary programs and institutes in the social sciences have shown very little interest. On the other hand, feminist theory has played a key part in both Britain and the USA, as has the post-Saidian critique of colonial and racist forms of thought. Again, individual influences will vary (e.g. Gramsci or psychoanalytical approaches in Britain), but the linguistic turn has been common to both, together with the fascination with postmodernism. For our purposes we may note that most concrete work has so far been strongly located in the present. In one sense, that doesn't matter, as the "long present" of cultural studies is essentially the period since 1945, i.e. almost half-a-century of historical time that badly needs historians' attention. But given the excitement currently surrounding a number of areas--e.g. cultures of consumption, economies of pleasure and desire; the growth of serious work on the visual technologies of film, photography, video and TV, and on commercial media like advertising, comic books, and magazines; the relationship of women in particular to popular reading genres (romances, gothic novels, family sagas), TV (soap operas, detective series, situation comedies), and film (film noir, horror, science fiction, melodrama); the use of autobiography and the personal voice; postcolonial cultural critique; and the general reopening of debates around high/low/popular culture--we may expect more historical work increasingly to accrue. [45] Work on popular memory 
and representations of the (usually national) past already forms a particular genre in this way. [46]

(e) I'd like to end this series of observations with a paradox. On the one hand, the earlier ambition of a "total history", of writing the history of society in some integrated and holistic way, has come radically into question. In one of my own less memorable essays just over a decade ago,. I argued that the most interesting feature of social history at the end of the 1970s was "its new totalizing potential". Now, it's possible to maintain some version of this claim still (e.g. the possibility of considering all phenomena and practices in their social dimensions), but the stronger form of the argument--"attempting to understand all facets of human existence in terms of their social determinations", as I put it-has become very problematic. [47] As I'Il argue below, the confident materialist conception of social totality--"society" in its Marxist and non-Marxist sociological forms--has for many social scientists and cultural theorists ceased to be the natural organizing belief. But on the other hand, a considerable body of historical sociology continues to be written much as: before, organized within the established problematics of state-making, the rise of capitalism, comparative political development, revolutions, and so on. [48] More than that, in fact, there has developed a new genre of world histories, extending literally from Mesopotamia to the global confrontation of the twentieth century, produced by leading British sociologists, seeking presumably to recapture the memories of their grammar school (or perhaps public school) history syllabus, essentially an attempt to rebuild social theory by writing the history of the world. [49] This creates an interesting juxtaposition. On the one hand, the radical diagnoses of the "postmodern condition" are proclaiming the demise of all master narratives; on the other hand, the most ambitious historical sociologists are defining their project by producing... a new range of grand narratives.

This is a truncated and selective survey of current developments, necessarily limited by the practical range of my own expertise. When considering the trajectory of social history since the 1970s, there is no doubt that much could be said in relation to major fields of production that I know only very imperfectly--such as most of US social history, the social history of:islave and post-emancipation societies in the Americas, African social history, the study of colonial and postcolonial societies in the Third World, and so on. But I have tried to pick out certain aspects of the present context which may provide a useful basis: for discussion.

\section{All the World's a Text}

Surveying the intellectual landscape of the social sciences at the end of the twentieth century, then, it's hard not to be impressed by the power and popularity of literary theory, linguistic analysis, and related forms of theoretical address. Whether we look to the revival of intellectual history and the influence of Dominick LaCapra, to the potential convergence of intellectual historians with literary critics in a "new historicist" mold, to the enormous impact of Edward Said, and now Gayatri Spivak, on intellectuals writing in and about the Third World, to the interest of Joan Scott and other feminists in theories of gender and language, to the pull of reflexive anthropology towards the narrative ordering of the experienced world, to formal analysis of the "rhetoric" of economics and other apparently non-literary disciplines, or simply to the common currency of terms like "discourse" and "deconstruction"--in all of these places there seems to be no escape. 
In: many ways, Hayden white is the patron saint of this development, for at an early stage (1973) his Metahistory problematized the boundaries between the humanities and the social sciences, and showed how works in the latter are also constructed around particular narrative and rhetorical strategies, even when bound at their'most rigorous and single-minded to the rules of evidence and scientific methodology. Moreover, White mounted this challenge from the older resources of literary criticism and his own original and idiosyncratic imagination, confronting "objectivist". history with the moral and aesthetic principles that order and inform its production. [50] In the meantime, the transformation of literary studies by the impact of (among others) Derrida and De Man has radicalized the challenge. The complexities of reading (and writing) have brought the category of the text and the work of interpretation into question. From focusing on authorial intention and the text's single attainable meaning (a chimera, that obscures the indeterminacy and necessary openness of the text, its "undecidability", its multiplicity of meanings), literary theory has sharpened the practice of reading to a point of technical sophistication where meanings can seemingly be endlessly disclosed. For outsiders it has often been hard to break into this magic circle without devoting oneself fulltime to learning a new language of cleverness and gesture, and sometimes it has seemed that a re-professionalizing of literature and an authorizing of the theorist, a technocracy of the word, has been precisely the point. Yet such suspicions can't occlude the actual influence of such theory beyond its immediate domain. For some modified appropriation of deconstruction's basic program--at its simplest, "a reading which involves seizing upon [texts'] inconsistencies and contradictions to break up the idea of a unified whole" [51]--has become very commonplace. For the social historian in particular, some notion of externality, what Derrida has called "the diachronic overdetermination of the context" or Raymond Williams' notion of determination as the setting of limits, is bound to loom important. [52] Probably this means focusing on two kinds of move--back, to the contexts of the text's production; and out, to the ways in which its meanings get constructed. Rather than what it:"means", in fact, it may be"more fruitful to understand how the text "works". As Tony Bennett puts it, with the characteristic Gramscian inflection on British cultural studies: "the text is a site on which varying meanings and effects may be produced according to the determinations within which the work is inscribed-determinations which are never single and given but plural and contested, locked in relations of struggle". [53] Moreover, this mode of analysis has been increasingly extended from written texts in the more conventional sense to all manner of documents, and indeed to experience, behavior, and events as well. From assailing the transparency of the text in the discourse of literary criticism, textuality has become a metaphor for reality in general:

Interestingly, the turn to literary theory as such within the social sciences has a longer history. Two of the major influences in cultural studies in Britain and the USA--Raymond Williams and Clifford Geertz--were formed in this way, Williams by his own disciplinary background in English literature in the late-1940s and 1950s, Geertz by an appropriation of literary critical method in the time of his initial impact between the late-1950s and mid-1960s. At one level, Geertz's iseminal essay, "Ideology as a Cultural System", affords a remarkable snapshot of US social science at the peak of its postwar self-confidence, frozen just at the moment in the mid-1960s when all hell is about to break loose. The main referential context is still set by Talcott Parsons and the Harvard Department of Social Relations, but it has also reached 
the point of incipient dissolution. Geertz's footnotes read like the epitaph of a vanished discourse, and in this sense the essay is a fascinating intellectual document, poised at the cusp of a transition, heavily laden with its own moment. The interesting thing is that when Geertz breaks free to formulate his theory of symbolic action, he does so in the direction of philosophy and literary criticism; and, of course, the philosophy and literary criticism he uses :are precisely, the ones available in the USA of the 1950s. [54]

When we turn to Raymond Williams and his equally seminal Culture and Society and The Long Revolution, which were produced in iroughly the same period, we find an intellectual formation locked just as firmly in its own national context, though here one which lacked any longer the power resources of an expanding metropolitan culture, which by contrast were carrying US social science to the four corners of the world: In Williams' case the immediate context was a very English dialogue with the criticism of $F$. R. Leavis and I. A. Richards and a political engagement with the problem of democracy and high culture. But one of the remarkable features of Williams' subsequent career--right up to his tragically early death in 1988--was his ability to move with the times--not in the limited sense of following fashions, but by consistently facing and assimilating the challenges of new theory. If we consider the fullness of his writing since the late-1960s, in fact, we find all the major theoretical influences that have been transforming understandings of culture/ideology since Geertz elaborated his first proposals--with the striking exception of Geertz himself and the wider corpus of US cultural anthropology, to whose existence Williams seemed largely indifferent. (The indifference remained mutual). Beginning with Central European aesthetics and philosophy (Lukacs, the Frankfurt School), and continuing through the French lineage of structuralisms and post-structuralisms, the appropriation of Gramsci, and the discovery of Voloshinov and Bakhtin, Williams both registered the reception of continental European theory and worked the latter into his own distinctive contribution. The essay, "Base and Superstructure in Marxist Cultural Theory" (1973), was one of the first installments in this process, anticipating the book-length Marxism and Literature (1977) and subsequent writings. Moreover, the openness of Williams' thinking was exemplary, and it would have been fascinating to have had his considered reflections on the emergent discourse of postmodernism in the later 1980s. [55]

Not the least of Williams' role and achievements during the 1970s and 1980 s was to have mediated the impact of literary theory in wider areas of social, cultural, and political discourse, and also--a point of connection more lacking perhaps in the USA than in Britain--in a wider political domain. For behind the theoretical discussions referred to above lies a more political challenge--that is, the unresolved agenda of the post-1968 intellectual radicalism which spawned the rich profusion of marxisms and feminisms that have done so much to shape the outlook of the affected generations of scholars in the last quarter of the twentieth century. Of course--and this is the departure point of my own reflections--since the heady days of the 1960s, when forms of "social" explanation carried all before them, grounding the imagination in the determinant causalities of an axiomatic materialism, a veritable flood has passed beneath the bridge. Moreover, the main current of the latter, despite the materialist beginnings just alluded to, has been an unrelenting anti-reductionism. At first, the new diffusion of Marxism--which for the first time established a broad presence in the universities of the English-speaking world--seemed to uphold the classical commitments of the 
tradition, whether in Althusser's "anti-humanist" separation of the mature from the young Marx, the more general structuralist stress on mode of production and an economically-centered concept of class, the revival of Marxist economics, Braverman-inspired studies of the labor process, or the feminist domestic labor dispute. Capital became reinstated as the starting-point. Yet at the same time, these discussions defined themselves in no uncertain terms as departures, as critical advances on the older forms of economistic theory. The "base/superstructure" model of social determination, with its assignment of logical priority to the economic, came under particular attack. The efforts of Althusser and Poulantzas blew a gaping hole in such orthodoxies, through which an army of mainly French influences--Lacanian psychoanalysis, Saussurian linguistics, the philosophy of science of Bachelard and Canguilhem, the aesthetics of Macherey, semiotics and theories of film, and so on--was then able to rush. This freeing of politics and ideology for "relatively autonomous" analysis, anchored to the economy via "structural causality" and "determination in the last instance", opened the whole domain of the "non-economic" to Marxist view--aesthetics, literature,.. the arts, theories of knowledge, science, education, religion, academic knowledge: and the disciplines, intellectual life, popular culture, sexuality, and so on--in short, "culture", as a convergent strain of British dissenting Marxism was coming to define it. [56]

The excitement of those days, the sense of participating in a continuous and unsettling process of revision, is worth remembering; and while the voice at this point is clearly personal (with a British.accent), it is also worth recognizing this as a remarkable generational achievement, which both internationalized (or at least Europeanized) a. previously parochial intellectual culture, wrenched it into an openly theorized mode of exchange, and simultaneously problematized the latter's terms of address. At the same time, there is also a danger of presenting this process as more unified, coherent, and logically continuous than it was (or could have been), so that one move followed rationally on another, causally inscribed in the contradictions and insufficiencies that preceded it. Yet intellectual histories are seldom as rationally constructed as this; and the process of revision was divisive rather than harmonious, instigated by conflicts and disruptions as much as by its own logical momentum. Feminism is by far the most important influence of this kind, and the reader may have noticed its regular reappearance in my text--not quite as a disruption, as my understanding of its importance is too controlled for that, but not quite as a fully integral primary theme either. I've puzzled over what to do about this, and perhaps this accurately captures the relationship of feminist to general theory or social historical discussion (always assuming that "general" in this: context is more than a synonym for androcentrism)--better, : that is, to keep the sense of relative apartness and ability to disturb the narrative and logical coherence of the account than to be smoothly assimilated to its structure (which would also be a dishonesty of its own). On the one hand, as Terry Lovell observes, contemporary feminist writing shows a trajectory that is recognizable in the terms I'm using:

"The journey begins with Marxist- or socialist-feminist writings (in history, social science and cultural studies), seeking to uncover the material conditions of women's oppression under capitalism; it advances with the recognition that certain aspects of that oppression do not yield very readily to Marxist categories and that a more adequate account of feminine subjectivity is required for an understanding of the ways in which that oppression is lived, which might be sought in psychoanalysis rather than Marxism. Then, via Lacan and modern theories of language, 
the journey continues into the 'poststructuralism' and 'deconstructionism' whose luminaries include Foucault, Derrida and Kristeva. Some travellers continue beyond feminism itself, into a 'postfeminism' and 'postmodernism' which understand both Lacanian psychoanalysis and Marxism to have been mere staging-posts along the way". [57]

On the other hand, it is still necessarily apart. As Sally Alexander puts it, in an essay which is still rather notable among social historians for. its willingness to engage theoretically with this issue:

"If feminism has been only one of the detonators of 'crisis' in marxist thought and practice it has been the most insistently subversive because it will not give up its wish to speak in the name of women; of women's experience, subjectivity and sexuality... We were asking the impossible perhaps. As a feminist I was (and still am) under the spell of those wishes, while as a historian writing and thinking in the shadow of a labour history which silences them. How can women speak and think creatively within marxism when they can neither enter the narrative flow as fully as they wish, nor imagine that there might be other subjectivities present in history than those of class (for to imagine that is to transgress the laws of historical materialism)?" [58]

Over the longer term, such discussions have played havoc with the received forms of Marxist and more general materialist understanding. For many, the logic of the anti-reductionist turn (as we might summarize the developments since the late-1960s) has been overpowering, leading eventually to the unanticipated embrace of a "post-Marxist" field of address, and the more predictable counter-reaction of those uncomfortable with such an apparent "retreat from class". [59] But what for some has been the feared Pandora's Box of uncontrollable heterodoxies remains for other a bottomless bag of tricks, which contains not only the anti-reductionist possibilities mentioned above, but the more daring options of postmodernism and the linguistic turn. This restless probing of the limits shows no signs of coming to a halt. Shibboleths have fallen one by one. By now, the further pursuit of the anti-reductionist logic during the 1980 s--through increasingly sophisticated readings of culture and ideology via Gramsci, Foucault, Voloshinov and Bakhtin, French poststructuralism, cultural studies in Britain, and the still-diversifying field of feminist theory on both sides of the. Atlantic--has left the earlier intellectual moment of the 1960s far behind, to the point of bringing the original materialist inspirations badly into doubt.

As the hold of the economy has been progressively loosened, and with it the determinative power of the social structure and its causal priorities, therefore, the imaginative and epistemological space for other kinds of analysis has grown. In fact, for many who have gone this route, the classical materialist connection has been broken once and for all. "Society" as a unitary object can no longer be maintained. There is no structural coherence deriving easily from the economy; from the functional needs of the social system and its central values, or from some other overarching principle of order. Particular phenomena--an event, a policy, an institution, an ideology, a text--have particular social contexts, in the sense of conditions, practices, sites, which conjoin for an essential part of their meaning. But there is no underlying given structure to which they can necessarily be referred, as its essential expression or necessary effects. In other words, the major casualty of this 
intellectual flux has been the confidence in a notion of social totality in its various marxist and non-marxist forms. The commitment to grasping society as a whole, to conceptualizing its underlying principles of unity--which is now conventionally described as the specifically "modern" or enlightenment project--has passed into crisis. For Marxists and others on the left this is also connected to a complex of political experiences; including the numerical decline of the historic working class and its traditions; the crisis of Keynesianism, the welfare state, $\therefore$ and statist conceptions of socialism; the economic, political, and moral bankruptcy of Communist systems; the catastrophe of the environment and of the scientific mastery over nature; and the declining purchase of straightforward class-political forms of address. As Lyotard says, the postmodern moment begins with an "incredulity with regard to master narratives". History, in this sense, has lost its way. The grand ideals that allowed us to read history in a particular direction, as a story of progress and emancipation, from the Industrial Revolution and the triumph: of science over nature, to the emancipation of the working class, the victory of socialism, and the equality of women, no longer persuade. All bets are off. "[T]here is no single right way to read history. Indeed history becomes a narrative without :a teleology", a story without an end. [60]

Thus the last two decades have seen a dizzying intellectual history. We have moved from a time when social history and social analysis seemed to be capturing the central ground of the profession and the force of social determinations seemed axiomatic, to a new conjuncture in which "the social" has come to seem ever less definite and social determinations have surrendered their previous sovereignty. The road from "relative autonomy" and "structural causality" (the hard-won gains of the 1970s) to the "discursive character of all practices" (the post-structuralist axiom of the 1980s) has been rapid and disconcerting, in which the persuasiveness of the anti-reductionist logic has been extraordinarily hard to withstand (rather like an up-escalator with no way down). But if "society" as a totalizing category is passing into dissolution, does that mean that social explanation as such has lost all independent efficacy? There is a sense in which the reception of Foucault and subsequent post-structuralisms has collapsed the distiction between the social and the cultural altogether (where the latter becomes a summary description for the entire discursive domain), so that the social formation (and hence the bases of inter-connectedness) becomes redefined agnostically as the aggregate of "discursive practices"--as "equivalent to the non unified totality of these practices", or as "a complex, overdetermined and contradictory nexus of discursive practices". [61] In that case, if social reality is only accessible via language (in the constitutive theoretical sense, as well as in the commonsense descriptive one which most would accept), and "the social" is only constituted through discourse, then what place is left for specifically social determinations at all?

This is the point that I take the discussion to have reached. A relatively small number of historians have taken the train to the end of the line, through the terrain of textuality to the land of discourse and deconstruction, to a radical epistemology "which "relativizes the status of all knowledge, links knowledge and power, and theorizes these in terms of the operations of difference". [62] This can be alternately empowering, in that its revelation of the "non-fixity" of meaning shows how social and political definitions may be questioned and how the terms of the given are always in play and therefore susceptible to challenge, in the present no less than the past, and disabling, to the extent that the critique of epistemology in its most radical forms undermines the idea 
of historical knowledge as such and reduces the historian's task to more or less elaborate forms of historiographical critique (history not as the archival reconstruction of what happened, but as the continuous contest over how the past is approached or invoked). A much larger group of social historians continues much as before, generally aware of what is happening, but uninterested in the theory behind the linguistic turn, and essentially wishing that it would go away. And then there are the rest of us, partly there for the ride, partly curious to see where it goes, and not at all sure we'll stay very long at the destination.

Now, this intermediate place (I hesitate to call it the "middle ground", because it certainly involves accepting the basic usefuleness and interest of post-structuralist theory to begin with--that is, being willing to get on the train in the first place) is in my view a very good one to be. It has some important virtues, pluralism chief among them. But it also has some real costs. It means giving up the claim to a distinct form of historical knowledge, let alone the aggrandizing and oft-repeated claim to being. somehow the "queen of the disciplines". History in the sense of the (mostly unreflected) practice of many or most historians does tend to a definite epistemology, which usually amounts to some brand of empiricism--that is, the belief in a knowable past, whose structures and processes are able to be distinguished from the forms of documentary representation, conceptual and political appropriations, and historiographical discourses that construct them. By now, I take the epistemological critique of this naive practice (or, more radically, the critique of epistemology per se as "a theoretical. domain that tries to state a mechanism of correspondence between a discourse and objects existing outside discourse which can be specified and made the measure of it") to be basic. [63]

But this doesn't mean that history becomes pointless or undo-able. On the one hand, rejecting a correspondence theory of truth does not mean that doing history becomes completely arbitrary, that the historian can somehow invent documents at will, or that rules of evidence become irrelevant (fears typically voiced by the linguistic turn's opponents). It does mean that criteria of truth have to be thought very differently. Knowledge is as "good" or "bad" as the quality of questions that constitute it: "Historical knowledge works by posing, re-posing and displacing questions, not by accumulating 'evidence' independently of them. Facts are not given, it is only relative to a question that we can begin to assess the value of those materials which are to constitute evidence for the answer to it". [64] As Stedman Jones said in his 1976 article, "history like any other 'social science' is an entirely intellectual operation which takes place in the present and in the head"; and: "The fact that the 'past' in some sense 'happened' is not of primary significance since the past is in no sense synonymous with history". In fact, the "real" past is beyond retrieval. Instead, the historian both evaluates documentary residues by the technical procedures of the profession and assigns them relevance via the construction of a significant problem. Accordingly, the common distinction between "history" and "theory" makes no sense: "The distinctian is not that between theory and non-theory, but between the adequacy or inadequacy of the theory brought to bear". [65] Moreover, the test of history's knowledge (its "truth") is not some general notion of epistemological validity ("truth-in-general"), but the particular criteria of adequacy and appropriateness that history, no less than other particular fields (from biblical scholarship to automobile mechanics), has tended to devise (and which will always themselves be subject to varying degrees of consensus and disagreement). 
On the other hand, history is simply unavoidable. It is constantly in play at the level of both everyday understanding and the formal discourses affecting social, economic, cultural, and political exchange. It is invoked and appropriated as a matter of course either implicitly or explicitly in order to make arguments; and for such arguments to be made (or countered) effectively, appropriate attention to the evidentiary conventions of the history profession will often need to be paid. But such conventions should not be mistaken for a viable epistemological claim. History's value is not as an archive, or a court of "real experience". It is as a site of difference, a context of deconstruction--partly because it is de facto always being fought over (i.e. invoked and appropriated in contestatory ways), partly because it affords the contexts in which the ever-seductive unities of contemporary social and political discourse, the naturalizing of hegemonies, can be upset. History is different not in the sense that it reveals earlier stages in our own story, or as an unapproachable realm of the exotic, but in the sense that the very notion of a single coherent and unified story can be unpicked:

"If [history] does not consist merely in the vindication of our own views of ourselves or in triumphalist accounts of modernity, it is because some historians can recognize that the past is different, not merely an earlier stage of our 'story', but a means of unsettling ourselves and investigating, however partially, what we are". [66]

Turning to History

Of course (the hard-bitten realists of the profession will say, patrolling their practice against these suggestions), such theory is all very well, but what difference does it really make? Worse, all this endless theorizing, the self-sustaining industry of critique, deflects one from more concrete and extended engagements with the past (whose pursuit, after all, remains the mundane justification for separate and specialized departments of history). Such attacks have become a familiar rhetorical move, intended to pre-empt, rather than to consider seriously, the theory concerned. But in an innocent form the complaint does contain a reasonable request. If the earlier assumptions of social history no longer hold, and the older notions of social totality and social determination can't suffice, then how can the practical project of a critical sucial. history--in dissertation and monographic form, as opposed to essay-critique--be reaffirmed? Some exemplary answer to this question, in however indicative a form, is clearly owed.

There are no ready-made solutions to the conundrum, but one extremely fruitful response to current uncertainties has been to historicize the category of "society" itself by specifying the terms of its own social, political, and intellectual history--that is, by looking at the terms under which "the social" first became abstracted into an object of theory-knowledge, a target of policy, and a site of practice, so that the material context in which society could be convincingly represented as an ultimately originating subject became gradually composed. [67] Here "the social" refers not to the global analytical category of "society" in some unproblematic social-science sense, but to the historically located methods, techniques, and practices that allowed such a category to be constructed in the first place. The impetus for such a perspective is unmistakable Foucault. His concept of the disciplinary society 
is concerned directly with this process. At one level, it profoundly shifts our understanding of politics, carrying the analysis of power away from the core institutions of the state in the national-centralized sense toward the emergence of new individualizing strategies "that function outside, below and alongside the State apparatuses, on a much more minute and everyday level". [68] But at another level, it is precisely through such individualizing strategies that society. ("the social" or the "social body") became recognized, constituted, and elaborated as the main object of science, surveillance, policy, and power. Population (fertility, age, mobility, health), economics, poverty, crime, education, welfare became not only the main objects of government activity, but also the measure of cohesion and solidarity in the emerging nineteenth-century social order. If we're to understand the latter, it is to the new social-science and medico-administrative discourses, their technologies, and effects that we must look--to the new knowledges "concerning society, its health and sickness, its conditions of life, housing and habits, which served as the basic core for the 'social economy' and sociology of the nineteenth century". [69] In the late nineteenth and early twentieth century, the repertoire of power-producing knowledges then further expands--through psychiatry and pyschology, social work and the welfare state, youth policy, industrial relations, public health, social hygiene, eugenics, and so on. As Donzelot and others have argued, the family becomes a particular object of such interventions and expertise. Moreover, as feminist scholars and Foucault's own final works have shown, sexuality provides an especially rich field for showing such power relations under construction. [70]

This "discursive" move--from the assumption of an objective "society" to the study of how the category of "the social" was formed--may be taken as paradigmatic for a variety of areas, and here I want to consider briefly two in particular, the procejss of working-class formation and the growth of citizenship ideals in the early nineteenth century, both of which have attracted some attention in this respect. Since Thompson it has been harder and harder to present the process of working-class formation as the logical unfolding of an economic process and its necessary effects at the levels of social organization, consciousness, and culture. But nor can we conduct the alternative analysis simply as a process of empirical disaggregation, so that a fuller grasp of the working class's compositional complexities (its sectional variety across industries, its internal differentiation by hierarchies of seniority, status and skill, and its cultural segmentation along lines of gender, religion, ethnicity, and race) and the time-scale of its coalescence can emerge. To understand class as a political factor, in fact, we have to go further and accept the intractable methodological and theoretical difficulties of analyzing working-class politics (the rise of labor movements and socialist parties) as the causal expression of an economically located class interest and social structural position, indeed the futility of ever achieving historiographical consensus to this effect (quite apart from the epistemological problems with such a notion of social causality discussed above). In this sense, class as a political and cultural postulate (the assertion of a particular model of social identity) was just as crucial to the process of class formation as the existence of class as a demonstrable social fact (the creation of new social positions defined by the relationship to the means of production or some other material criteria). The ideology of class, the insistence that class was the organizing reality of the emerging capitalist societies, and the growth of sepcific practices and organizations around that insistence (like trade unions and socialist parties), is arguably a better starting-point for the study of class formation than the classical one of economics and social structure, 
because it was at this discursive level that the operational collectivity of class--who got to be included, who set the tone, and who received the recognized voice--was defined. In these terms, the history of a class is inseparable from the history of the category. Class emerged as a set of discursive claims about the social world seeking to reorder that world in terms of itself.

A move of this kind helps us free analysis from the teleology of a class cosciousness thought to be inscribed in the structures of class interest and class-collective experience--and from the need to find special explanations when that class consciousness is imperfectly, if at all, achieved. Indeed, it converts the notion of "interest" itself into a problem, a discursive effect of complex histories rather than a given, coherent, and agreed basis for action that's causally prior. Rather than asking which working-class interests were reflected in which organizations and forms of action (so that working-class consciousness becomes expressively derived), we should start asking how the prevailing understandings of working-class interest were produced, how particular practices and institutions encouraged or hindered particular constructions of working-class interest, and how one specific set of images of what the working class was came to be entrenched. From this perspective, "interest" is far more an effect than a cause.

Focusing on the construction of class as a structuring and motivating category in this way gives us better access to the partialities and indeterminacies of class formation and to the processes of exclusion on which its solidarities grew. And in exploring the always-incomplete process of construction which thus defines class as an operative phenomenon, we should concentrate less on uncovering an underlying coherence in the languages of class than on understanding their lines of fracture and difference. As Robbie Gray observes, reflecting on Stedman Jones' intervention, such language is "multi-layered, complex, fractured, composed of incoherences and silences, as well as the smooth flow of would-be authoritative public discourses", and as such must be read for its exclusions as well as for its unifying appeals. [71] The most important and continuous of such exclusions has concerned women and is ordered along lines of gender. The positive identity of the working class as it became elaborated during the nineteenth century--the ideal of skilled male worker in industry--rested on powerfully dichotomous assumptions about what it meant to be a man or woman. Those assumptions were ordered into a: pervasive dualism that aligned men with the worlds of work and the public domain of politics and women with the home and the private realm of domesticity, the one a site of control and rationality, the other a site of affect and subordination. Inscribed in the language of class were definite notions of masculinity and femininity which limited "women's access to knowledge, skill and independent political subjectivity". [72] Consequently, the importance of gender, sexuality, and family can't be bracketed from an account of the politics of working-class formation. On the contrary, the social construction of sexual difference in such a way that it did work to separate the private sphere of family from the worlds of work and class--the gendering of class formation--actually had a powerful impact on how working-class identity came to be understood. Moreover, the fixing of class identity in this way presupposed the suppression of alternative possibilities. Such a fixing presumed, indeed required, the silencing of alternative meanings that threatened to outgrow its terms. In the case of "class", the discourse marginalizes the role of women through the fixity of its assumptions in this way. It seems to me enormously important to uncover such structures and their operation and convert the assumed meanings of class into a problem. It's vital, in other words, to upset the unity of meaning. 
In fact, we need an opposing conception of identity which stresses its non-fixity and sees it as an unstable ordering of multiple possibilities whose provisional unity is managed discursively through language and is only ever constituted through incompletely ordered factors of difference. If the purpose is to understand the ways in which processes and structures of exclusion have ordered historical constructions of class, then overcoming such exclusions means recognizing the indeterminate multiplicity of identity. How we see ourselves as a basis for action, and how we are addressed in the public arena, is not fixed. We recognize ourselves variously--as citizens, as workers, as parents, as consumers, as enthusiasts for sports or hobbies, as religious believers, and so on; those recognitions are inflected with power relations of different kinds; and they are heavily gendered by assumptions defining us as women or men. At one level, this complexity and non-fixity of subject positions is a banal observation. But the important thing is that politics is usually: conducted as if identity is fixed. The issue then becomes: on what bases, in different places and: at different times, does identity's non-fixity become temporarily fixed in such a way to enable individuals and groups to behave as a particular kind of agency, political or otherwise? How do people become shaped into acting subjects, understanding themselves in particular ways? In effect, politics consists of the effort to "domesticate the infinitude" of identity. [73] It is the attempt to hegemonize identity, to order it into strong programmatic: commitments. If identity is de-centered, politics is about the attempt to create a center.

To return to the question of working-class formation, the power of the socialist tradition between the late nineteenth century and the 1930s (reaching a long denouement in our own time) was its ability to harness popular identities to a strong conception of the working class--that is, to construct popular political agency around the discourse of class in its classical gendered, skilled, nationally-bounded, industrial sense. Now, in all periods and places such parties were always more complex in their sociology than this, whether in membership, support, or appeal. They mobilized workers, even in the restrictive definition, highly unevenly; and they always integrated wider sections of the populace around the male, skilled, religious, and ethnic core, whether these other constituencies were working-class in the fuller sociological sense (e.g. women, the unskilled, national minorities, etc.) or not working-class at all as that was classically understood (like dissenting intellectuals; certain sections of the professions, clerical and other white-collar workers, shopkeepers and other small business people in working-class neighborhoods, and so on): Moreover, socialist parties were always active in "non-class" ways, working through the public rhetoric of democratic citizenship, social justice, and egalitarianism as much as through the language of socialism per se. But programmatically, the centering of their practice around the notion of class is clear enough. And concentrating identity in that way has its costs. It involves a reduction to class. It involves exclusions and neglects. The positive orientation toward the working class presumed a negative orientation to others--and not just to other classes, but to other kinds of workers too (e.g. the unorganized, the rough and unrespectable, the criminal, the frivolous, the religiously devout, the ethnically different, and of course the female), and to other elements of subjectivity, in effect all the aspects of identity that couldn't be disciplined into a highly centered notion of class-political agency. Moreover, the neglect of that space--the space defined by these "other" identities--provides opportunities for other labors of construction to occur, coming from the state, political competitors, the churches, commercial entertainment, and so on. 
Thus the "unity" of the working class, though postulated through the analysis of production and its social relations, is a never-attainable object of construction, a fictive agency, a contingency of political action.

Moreover, notions of citizenship can be similarly deconstructed, particularly if we push these back to the ideal: of the rationally acting individual subject usually located in the traditions of thought descending from the Enlightenment. It has become a commonplace of feminist critique that modern political thought is highly gendered in its basic structures, particularly in the Enlightenment context of the later eighteenth century when the key elements of liberal and democratic discourse were first composed. In other words, the constitutive moment of modern political understanding was itself constituted by newly conceived or rearranged assumptions about woman and man: this was not only visible in constitutions, legal codes, and political mobilizations, but also ordered the higher philosophical discourse around the universals of reason, law, and nature, grounding this in an ideologically constructed system of differences in gender. The new category of the "public man" and his "virtue" was elaborated via a series of oppositions to "femininity", which both drew upon older notions of domesticity and women's place and rationalized them into a set of formal claims concerning woman's "nature". At the most fundamental level, specific constructions of "womanness" defined the quality of being a "man", so that the natural identification of sexuality and desire with the feminine allowed the social and political construction of masculinity. In this sense, modern politics, among other things, was constituted "as a relation of gender". [74] In the rhetoric of the 1780 s and 1790 s reason was counterposed conventionally to "femininity, if by the latter we mean (as contemporaries did) pleasure, play, eroticism, artifice, style, politesse, refined facades, and particularity". [75] Then, in the concentrated circumstances of the French Revolution, women were to be silenced to allow masculine speech--in the language of reason-full rein. Together with others (class, race, ethnicity, religion, age, etc.), gender and sexual identity were the powerful exclusions from which the modern political subject became formed--indeed, which allowed that idea of rational subjectivity first to emerge.

There is no need to explicate this further. The point is to suggest how particular discursive formations--whose emergence and elaboration can be carefully located historically--are themselves centrally implicated in social history, in constituting the basic categories of understanding and therefore the social, cultural and political environment in which people acted and thought, rather than being predicated on "experience" or following unproblematically from a social cause. The nineteenth-century discourse of citizenship, no less than the related conceptions of class-collective identity, were immensely complex and powerful formations of this type, which finely ordered the social and political world and structured the possibilities of what could and could not be thought. Gender was crucial not only to the patterning and containment of one's class identity, but also to the endowment and delimitation of one's political capacities. Recent feminist theory has acutely sensitized us to the procedures and assumptions which regulate access to a political voice. On the one hand, there is the synthesizing critique of patriarchy as a continuous figure of European political thought from Hobbes through Locke to the Enlightenment and beyond. In the latter women are essentially confined within the household: "Within this sphere, women's functions of child-bearing, child-rearing and maintaining the household are deemed to correspond to their unreason, disorderliness and 'closeness' to nature. Women and the domestic sphere are viewed as inferior to the male-dominated 'public: :world of civil society and its culture, property, 
social power, reason and freedom". [76] But on the other hand, the beauty of recent work is to have shown how this pattern of subordination was reformulated and recharged in the midst of that: major political cataclysm--the French Revolution--through which the ideal of human emancipation was otherwise radically enlarged. In other words, the emerging liberal model of rational political exchange was not just vitiated by persisting patriarchal structures of an older sort; the very inception of the liberal public sphere was itself shaped by a new exclusionary discourse directed at women.

In highlighting the exclusionary treatment of women, such work is also subverting the existing terms of the story--enabling not just the retrieval of a previously neglected aspect, but a set of insights that fundamentally reconstructs our sense of the whole. There are now rich demonstrations in a variety of fields to this effect. Thus Davidoff and Hall have shown how classical bourgeois society and politics no less than the nineteenth-century working-class presence were also produced by gendered processes of class formation. They stress both the constitutive importance of gender (i.e. the historically specific structuring of sexual difference) in the ordering of the middle-class social world via particular patterns of family and domesticity and particular styles of consumption, and the reciprocal interactions between this private sphere and the public sphere of associational life: and politics, in which the latter both reflected and actively reproduced the gendered distinctions of class identity generated between home and work. The remarkable associational activity of the early nineteenth century strictly demarcated the roles of women and men via a mobile repertoire of ideologies and practices, which consistently assigned women to a non-political private sphere, "having at most a supportive role to play in the rapidly expanding political world of their fathers, husbands and brothers". [77] Moreover, this separation of spheres--between :the masculine realm of public activity and the feminine realm of the home, which certainly didn't preclude (and was finely articulated with) relations of interconnectedness between business/occupation and household, and engendered a particular conception of the public and the private for the emergent nineteenth-century bourgeoisie--was replicated: in the situation of the working class, as work on Chartism and nineteenth-century socialist movements and the social history of the working class has amply shown. [78]

\section{Conclusion}

In this paper I have tried to take stock of the last twenty years, not to provide an accurate inventory of recent work, but to provide a sense of current direction. However, while the 1970 s were still characterized by a sense of forward movement, borne by the unlimited power of social explanation, the 1980s .have seen far more a mood of uncertainty and flux. As I've suggested, this is partly argenerational story, as one part of the sixties social history cohort has detached itself from the previous materialist consensus (as we can minimally call it) to pursue the anti-reductionist logic of structuralist and post-structuralist theory, leaving another part (probably the majority) in considerable disarray--some dogmatically reaffirming older positions (which: I've tended to call "classically materialist"), some opting for a more eclectic and anthropologically oriented cultural history, and many more continuing in their hard-won social-historical practice of the 1970s. At the risk of over-simplifying, I tend to see two main tributaries among English-speaking social historians to the linguistic turn: one the large corpus of British post-Althusserian Marxism/post-Marxism (including a separate but convergent feminism); and the other the remarkable North American impact of deconstructive literary theory, increasingly mediated through specifically feminist discussion. 
(Where this leaves the specifically anthropological contribution is less clear). At this point, the radical pressure of feminist theory seems to me to be primary. At all events, social history in its amorphous but aggrandizing form of the 1970s has ceased to exist: it has lost its coherence as an intellectual project (which derived, I suggested, from the sovereignty of social determinations within a self-confident materialist conception of social totality; both of which have been subjected to compelling critique); and it has lost its prestige as the natural location for the more radical, innovative, and experimental intellectual spirits in: the profession, particularly in the generations currently being recruited. The "new cultural history" or cultural studies is currently taking its place.

I don't see this as a crisis or cause for regret. There is certainly no shortage of voices who do. In the most recent--and book-length--example, Bryan Palmer denounces the linguistic turn as "unmistakably an adversary manouver" directed against historical materialism and social history. It represents a "hedonistic descent into a plurality of discourses that decenter the world in a chaotic denial of any acknowledgement of tangible structures of power and comprehensions of meaning"; a "reduction of analysis and theory to the puns and word games of: scholastic pretension"; and "a messianic faddism" which has disastrously captured the imagination of social historians. [79] Palmer's is truly a bizarre book, oscillating abruptly between sympathetic exegeses of post-structuralist contributions and constructive appropriations on the one hand and wild condemnations on the other. In the end, for Palmer the linguistic turn has resulted straightforwardly in "...crap, a kind of academic wordplaying with no possible link to anything but the pseudo-intellectualized ghettoes of the most self-promotionally avant-garde enclaves of that bastion of protectionism, the University". [80] Against this kind of intellectual police action ("These are refusals that must be made, : and made clearly"-ibut according to what authority?), which is depressingly reminiscent: of the worst excesses of Edward Thompson's The Poverty of Theory and the surrounding debate, we should insist on the need for pluralism. And that is the note on which I prefer to end. Whether individually we decide to take the linguistic turn. or not, there will remain a diversity of histories in the profession, and as in practice there is no way- of finally resolving these debates short of driving the opponents from the field and burning their books, the best we can ask is openness and intellectual seriousness in the exchange. Understanding advances through conflict and the polemical clarification of difference. But in the end it is the differences that: have to remain. 
Notes

1. E. J. Hobsbawm, "From Social History to the History of Society", Daedalus, 100 (1971), p. 43.

2. Several essays from the later 1970 s are repeatedly cited for these polemical disagreements: Elizabeth Fox Genovese and Eugene Genovese, "The Political Crisis of Social History: A Marxian Perspective", JSH, 10 (1976), pp. 205-20; Gareth Stedman Jones, "From Historical Sociology to Theoretical History", British Journal of Sociology, 27 (1976), pp. 295-305; Lawrence Stone,; "History and the Social Sciences in the Twentieth Century", in Charles F. Delzell (ed.), The Future of History (Nashville, 1977), pp. ; Tony Judt, "A Clown in Regal Purple: Social History and the Historians", HWJ, 7 (Spring 1979), pp. 66-94. They were followed by Lawrence Stone, "The Revival of Narrative", P\&P, 85 (Nov. 1979), pp. 3-24; and Geoff Eley and Keith Nield, "Why Does Social History Ignore Politics?", SH, 5 (1980), pp. 249-71.

3. See the following of Stedman Jones' essays: "History: The Poverty of Empiricism", in Robin Blackburn (ed.), Ideology in Social Science. Readings in Critical Social Theory (London, 1972), pp. 96-115; "Class Struggle and the Industrial Revolution", NLR, 90 (March-April 1975), pp. - ; "Society and Politics at the Beginning of the World Economy", Cambridge Journal of Economics, 1 (1977), pp. 77-92; "Class Expression versus Social Control? A Critique of Recent Trends in the Social History of 'Leisure'", HWJ, 4 (Autumn 1977), 162-170; "From Historical Sociology to Theoretical History!" (cited note 2). The essay on language was "Rethinking Chartism", in Stedman Jones, Languages of Class. Studies in: English Working-Class History 1832-1982 (Cambridge, 1983), pp. 90-178, a volume which also republished several of the other essays. The best guide to the trajectory of Stedman Jones' thinking is the 'Introduction to Languages of Class, pp. 1-24, and an interview: conducted by Stuart Macintyre in Red Shift, 4 (1977), pp. 19-23:

4. Peter Novick, That Noble Dream. The "Objectivity Question". and the American Historical Profession (Cambridge, 1988), p. 605.

5. In CSSH post-structuralist perspectives have begun to enter to some extent via anthropology. My comments refer to the specifically historical component of the journal's contents, where the main orientation remains heavily social-science. The review essays are a partial exception to this.

6. Note also the ten-year retrospective editorial, "Ten Years After", (20, Autumn 1985, 1-4), which situates the development politically in relation to Thatcherism. A similar shift could be described in RHR, from the theme-issue on British Marxist history (19, Winter 1978-79), through one on "The Return of Narrative" (31, 1985) to one on "Language, Work and Ideology". (34, 1986). Interestingly, the theme-issue on "Sexuality in History" (20, Spring-Summer 1979) contains relatively little evidence of the new perspectives. One key article was Donald Reid's discussion of Jacques Rancière, "The Night of the Proletarians. Deconstruction and Social History", RHR, 28-30 (1984), pp. 445-63.

7. See E. P. Thompson, The Poverty of Theory and Other Essays (London, 1978), and the coinciding debate around Richard Johnson, "Thompson, Genovese, and Socialist-Humanist History", HWJ, 6 (Autumn 1978), 
pp. 79-100. Other contributions include Perry Anderson, Arguments within English Marxism (London, 1980), and the debate among Stuart Hall, Richard Johnson, and Edward Thompson at the Thirteenth History Workshop in Oxford in December 1979, published in Raphael Samuel (ed.)., People's History and Socialist Theory (London, 1981), pp. 375-408. (It is worth noting that a fourth, feminist, speaker was originally to join the History Workshop debate, but on the occasion withdrew on the grounds that the tone and terms of the proceedings made her presence inappropriate). There are many subsequent commentaries, and my favorite is Susan Magarey, "That Hoary old Chestnut, Free Will and Determinism: Culture vs. Structure, or History vs. Theory in Britain", CSSH, 29 (1987), pp. 626-39.

8. My reasons are also partly mischevous. The brief position papers produced for this occasion were published by the Tillys as "Problems in Social History: A Symposium" in Theory and Society, 9 (Sept. 1980), pp. 667-81, including those by Louise Tilly, Edward Shorter, Francis G. Couvares, David Levine, and Charles Tilly. The only such paper not solicited for the published symposium (as I discovered when it appeared) was my own, presumably on grounds of quality.

9. None of the intensity or concluding explosiveness of these discussions is hinted at in the published account.

10. Couvares, "Telling a Story in Context; or, What's Wrong With Social History?", ibid., p. 675.

11. Charles Tilly, "Two Callings of Social History", ibid., p. 681.

12. Louise A. Tilly, "Social History and its Critics", ibid., p.670.

13. The first of these titles was co-authored by Louise Tilly and Joan Scott, the second collects Joan Scott's intervening essays and documents the striking intellectual distance.

14. See especially Stedman Jones, "History: The Poverty of Empiricism"; "Class Expression versus Social Control?"; and "From Historical Sociology to Theoretical History". For a particular case, see Terrence J. McDonald, "The Problem of the Political in Recent American Urban History: Liberal Pluralism and the Rise of Functionalism", SH; 10 (1985), pp. 323-45. The best general illustration of this point is Past and Present between the late-1950s and late-1960s, where the generation of British Marxists who mainly left the Communist Party in 1956-57 turned to non-Marxist social theory as part of their general rethinking. Philip Abrams and Eric Hobsbawm were key in the exchange with sociology, Jack Goody, Peter Worsley, Keith Thomas, and Hobsbawm again in that with anthropology.

15. See Stedman Jones, "Class Expression"; McDonald, "Problem of the Political"; Craig J: Calhoun, "'Community': Toward a Variable Conceptualization for Comparative Research", SH, 5 (1980), pp. 105-29; Peter Gatrell, "Historians and Peasants: Studies of Medieval English Society in a Russian Context", P\&P, 96 (Aug. 1982), pp. 22-50.

16. See William H. Sewell, Jr., Work and Revolution in France. The Language of Labor from the 0ld Regime to 1848 (Cambridge, 1980), esp. pp. 10-13. See also the two essays by Bernard S. Cohn, "History and Anthropology: 
The State of Play", CSSH, 22 (1980), pp. 198-221, and "History and Anthropology: Towards a Rapprochement?", JIH, 12 (1981), pp. 227-52; Hans Medick, "'Missionaries in the Row Boat'? Ethnological Ways of Knowing as a Challenge to Social History", CSSH, 29 (1987), pp. 76-98; Gerald M. Sider, Culture and Class in Anthropology and History: A Newfoundland Illustration (Cambridge, 1986).

17. See Scott, Gender and the Politics of History. For Richard Johnson, see especially "Thompson, Genovese, and Socialist-Humanist History", and his two essays, "Culture and the Historians", and "Three Problematics: Elements of a Theory of Working-Class Culture", in John Clarke, Chas Critcher and Richard Johnson (eds.), Working-Class Culture. Studies in History and Theory (London, 1979), pp. 41-71 and 201-37. More recently see his "What is Cultural Studies Anyway?", Social Text, 16 (Winter 1986-87), pp. 38-80. Both Scott and Johnson began their careers in the 1960 s in the more dependent relationship criticized by Stedman Jones, cultivating their analysis in the sun of sociology--Scott with The Glassworkers of Carmaux: French Craftsmen and Political Action in a Nineteenth-Century City (Cambridge, Mass., 1974), Johnson as a historian of education within a perspective of social control. See Johnson, "Educational Policy and Social Control in Early-Victorian England", P\&P, 49 (Nov. 1970), pp. 96-119.

18. See the following: John E. Toews, "Intellectual History after the Linguistic Turn: The Autonomy of Meaning and the Irreducibility of Experience", AHR, 92 (Oct. 1987), 879-907; David Harlan, "Intellectual History and the Return of Literature", together with the response by David $A$. Hollinger, "The Return of the Prodigal: The Persistence of Historical Knowing", and Harlan's reply, AHR, 94 (June 1989), pp. 581-609, 610-21, and 622-26; Allan Megill, "Recounting the Past: 'Description', Explanation, and Narrative in Historiography", AHR, 94 (June 1989), pp. 627-53; AHR Forum on "The Old History and the New" (Theodore S. Hamerow, Gertrude Himmelfarb, Lawrence W. Levine, Joan Wallach Scott, John E. Toews), AHR, 94 (June 1989), pp. 654-98; Joyce Appleby, "One Good Turn Deserves Another: Moving Beyond the Linguistic; A Response to David Harlan", AHR, 94 (Dec. 1989), pp. 1326-32; Fred Matthews, "The Attack on 'Historicism': Allan Bloom's Indictment of Contemporary American Histurical Scholarship", AHR, 95 (April 1990), pp. 429-47; Thomas Childers, "The Social Language of Politics in Germany: The Sociology of Political Discourse in the Weimar Republic", AHR, 95 (April 1990), pp. 331-58; Roger Chartier, "Text, Symbols, and Frenchness", JMH, 57 (1985), pp. 682-95; Robert Darnton, "The Symbolic Element in History", JMH, 58 (1986), pp. 218-34; Dominick LaCapra, "Chartier, Darnton, and the Great Symbol Massacre", JMH, 60 (1988), pp. 95-112; James Fernandez, "Historians Tell Tales: Of Cartesian Cats and Gallic Cockfights", JMH, 60 (1988), pp. 113-27.

19. See David Abraham, The Collapse of the Weimar Republic: Political Economy and Crisis (Princeton, N.J., 1981), and the exhaustive exchange between Abraham and his main persecutor, Gerald D. Feldman, in Central European History, 17 (June-September 1984), pp. 91-293. There is a good presentation of this affair in Novick, That Noble Dream, pp. 612-21.

20. Renate Bridenthal, "Beyond Kinder, Küche, Kirche: Weimar Women at Work", CEH, 6 (June 1973), pp. 148-66; Jean H. Quataert, "A Source 
Analysis of German Women':s History: Factory Inspectors' Reports and the Shaping of Working-Class Lives, 1878-1914", CEH, 16 (June 1983), pp. 99-121; Deborah Hertz, "Intermarriage in the Berlin Salons", CEH, 16 (Dec. 1983), pp. 303-46; Jean H. Quataert, "The Politics of Rural Industrialization: Class, Gender, and Collective Protest in the Saxon Oberlausitz in the Late Nineteenth Century", CEH, 20 (June 1987), pp. 91-124. These figures are based on the cumulative Index to vols. 1-20 (1968-1987) in CEH, 20 (Sept.-Dec. 1987).

21. A good example of the change would be Rudy Koshar, who attended the Michigan conference "Whence and Whither Social History" in October 1979 as a finishing PhD student of Charles Tilly, and whose book, Social Life, Local Politics, and Nazism: Marburg, 1880-1935 (Chapel Hill, 1986), is among other things an excellent exploration of the historical uses of resource mobilization theory. By the conferences of 1989-90 listed above Koshar had re-emerged as probably the most radical post-structuralist among the participants. See, for instance, his unpublished papers for Chicago, "Representations, Symbols, Monuments", and Philadelphia, "The Kaiserreich as Ruin: Notes on Constructing the Popular Culture of Imperial Germany". Similar shifts might be traced in the French field, juxtaposing the current work of figures like William Sewell, Lynn Hunt, and in France Francois Furet with the kind of social history they apparently stood for in the late-1960s/early-1970s. In France itself the political referents of the shift have been different and extremely national-specific, deriving from the extraordinary anti-Marxism of contemporary French intellectual life. Thus in Furet's case the advocacy has moved away from social history to intellectual and political history, but hardly toward gender or language in the more radical sense. At the same time, the detailed picture in France remains more diverse: for an indication,: see Maurice Godelier, "Work and its Representations: A Research Proposal", and Pierre Achard, "History and the Politics of Language in France: A Review Essay", HWJ, 10 (Autumn 1980), pp. 164-74 and 175-83; and more recently, Peter Schöttler, "Historians and Discourse Analysis", HWJ, 27 (Spring 1989), pp. 37-65.

22. Hobsbawm, "From Social History to the History of Society", p. 12.

23. This is reflected in the Introduction to Pat Thane and Anthony Sutcliffe (eds:), Essays in Social History, vol. 2 (Oxford, 1986), which is conscious ly framed to update Hobsbawm's survey, but which presents a very disorganized melange of topics and trends. Ultimately, a general shift from "class" to "culture" in the organizing categories of British social history seems to be their overriding theme.

24. The apogee of achievement is E. A. Wrigley and Roger S. Schofield, The Population History of England 1541-1871 (Cambridge, 1981); and for easier access, see Kenneth Lockridge, "Brilliance and Whiggery", CSSH, 26 (April 1984), pp. 297-304, and E. A. Wrigley, Continuity, Chance and Change. The Character of the Industrial Revolution in England (Cambridge, 1988). The launching of the new journal, Continuity and Change. A Journal of Social Structure, Law and Demography in Past Societies (1986-), may presage a broadening of vision. In the meantime, see David Levine, Reproducing Families. The Political Economy of English History (Cambridge, 1987); Wally Seccombe, "Marxism and Demography!"; NLR, 137 (Jan.-Feb. 1983), pp. 22-47; Steve Hochstadt, "Social History and Politics: A Materialist View", $\underline{S H}, 7$ (Jan. 1982), pp. 75-83. 
25. Specific urban phenomena naturally retain their importance, as opposed to the claims of urban history as a coherent field in itself. Urban planning, the fiscal dimensions of the local state, Third World urbanization since the 1960s, the city as the cultural ideal of modernism--these and other themes come readily to mind. It is the exaggerated expectations invested in urban history as a sub-disciplinary specialism that seem to have come aground.

26. The literature on peasants may be best:approached through the journal of Peasant Studies (1973-74-). For the petty bourgeoisie, see David Blackbourn, "Economic Crisis and the Petite Bourgeoisie in Europe during the Nineteenth and Twentieth Centuries", SH, 10 (Jan. 1985), pp. 95-104, and Geoffrey Crossick and Gerhard Haupt (eds.), Shopkeepers and Master Artisans in Nineteenth-Century Europe (London, 1984). The most elaborate recent project on the bourgeoisie has been German-centered with extensive comparative ambitions, co-ordinated by Jürgen Kocka at the University of Bielefeld. See especially, Jürgen Kocka (ed.), Bürgertum im 19. Jahrhundert. Deutschland im europäischen Vergleich, 3 Vols. (Munich, 1988); and for an English-language collection in counter-position, David Blackbourn and Richard J. Evans (eds.), The German Bourgeoisie (London, 1990). There is also much activity in Italy, for which see the reports in the Bollettino di informazione a cura del gruppo di studio sulle borghesie del xix secolo (1985--). The role of gender in bourgeois class formation has also received important attention. See especially: Leonoie Davidoff and Catherine Hall, Family Fortunes. Men and Women of the English Middle Class, 1780-1850 (London, 1987); Mary. P. Ryan, Cradle of the Middle Class: Family and Community in Oneida County, New York, 1780-1865 (Cambridge, 1981); Ute Frevert (ed.), Bürgerinnen und Bürger. Geschlechterverhältnisse im 19. Jahrhundert (Göttingen, 1988).

27. On the other hand, Hobsbawm was well aware of the importance of matters like the sexual division of labor or women's political emancipation, andishis labor history writings showed both the relative strengths and the blindnesses of the Communist political tradition in this respect. The difference can be gauged by considering someone of a similar generation whose lack of awareness was genuinely crass: Harold Perkin, "What is Social History?", in The Structured Crowd: Essays in English Social History (Brighton, 1981), pp. 1-27.

28. Degler's essay is called "Women and the Family", in Kammen (ed.), Past:-Before Us, pp. 308-26 (published, don't forget, as recently as 1980). For an excellent overview of a critical kind, see Nancy. A. Hewitt, "Beyond the Search for Sisterhood: American Women's History in the 1980s", SH, 10 (Oct. 1985), pp. 299-321.

29. E.g. for:work on-Britain, Sally Alexander, "Women's Work in Nineteenth-Century London", in Juliet Mitchell and Ann Oakley (eds.), The Rights and Wrongs of Women (Harmondsworth, 1976), pp. 59-111, and "Women, Class and Sexual Difference", HWJ, 17 (Spring 1984), pp. 125-49; Sonya 0. Rose, "Gender at Work: Sex, Class and Industrial Capitalism", HWJ, 21 (Spring 1986), pp. 113-31; Mary Freifield, "Technical Change and the Self-Acting Mole", SH, 11 (Oct. 1986), pp. 319-43; Angela John (ed.), Unequal Opportunities: Women's Employment in England 1800-1918 
(0xford, 1986); and the special issue of Social History on "Gender and Employment", with articles by Shirley Dex, Jane Mark-Lawson and Anne Wilz, Ellen Jordan, Sonya 0. Rose, and Mike Savage, 13 (May 1988), pp. 141-230. Similar bibliographical indications could be given for Germany, France, and the USA. However, the progress should not be exaggerated: astonishingly, one recent imposing handbuch of international research, Klaus Tenfelde (ed.), Arbeiter und Arbeiterbewegung im Vergleich (Historische Zeitschrift Sonderhefte, Vol. 15) (Munich, 1986), contains among its twenty mainly: thematic essays no single entry on women.

30. Here the influehce of Joan Scott's Gender and the Politics of History is obviously important, together with works such as those by Davidoff and $\mathrm{Hall}$ and Ryan mentioned in note 26 above. I should also acknowledge two unpublished papers by my colleague Kathleen Canning, "Rethinking German Labor History: Gender and the Politics of Class Formation", and "Gender and the Culture of Work in the Kaiserreich". Again, the impact of this work on more orthodox discussions of class formation, even where these profess some commitment to innovation, shouldn't: be overstated. See, for instance, the influential volume edited by Ira Katznelson and Aristide R. Zolberg, Working-Class Formation. NineteenthCentury Patterns in Western Europe and the United States (Princeton, 1986), where gender relations are glaring in their absence (apart from a: lamely exculpatory footnote on the second page of the Introduction, p. 4).

31. E.g. Joan B. Landes, Women and the Public Sphere in the Age of the French Revolution (Ithaca, 1988); Carole Pateman, The Sexual Contract (Cambridge, 1988); Jean Bethke Elshtain, Public Man, Private Woman: Women in Social and Political Thought (Princeton, 1981); Ellen Kennedy and Susan Mendus (eds.), Women in Western Politicical Philosophy: Kant to Nietzsche (New York, 1987); Harriet B. Applewhite and Darline G. Levy (eds.), Women and Politics in the Age of the Democratic Revolution (Ann Arbor, 1990); Dorinda Outram, The Body and the French Revolution: Sex, Class and Political Culture (London and New Haven, 1989); Catherine Hall, "Private Persons versus Public Someones: Class, Gender and Politics in England:; 1780-1850", in Carolyn Steedman, Cathy Urwin and Valerie Walkerdine (eds.), Language, Gender and Childhood (London, 1985), pp. 10-33.

32. This has become an area of great activity, most of which, however, is strongly present-based. Much of the: most? interesting work can be found in a range of new journals, including New Formations [1987-], Block [1979--89] Cultural Stuties [1987-], Social Text [1982--], Qultiral Critique [1985--], Pepresentations [1983--], Media, culture, and Society [1978--], as well as in the women's studies journals. But a selective list of key works might include the following: Laura Mulvey, Visual and Other Pleasures (Bloomington and Indianapolis, 1989); Judith Williamson, Consuming Passions. The Dynamics of Popular Culture (London, 1986); Rosalind Coward, Female Desires. How They Are Sought, Bought and Packaged (London, 1984); Lorraine Gamman and Margaret Marshment (eds.), The Female Gaze. Women as Viewers of Popular Culture (London, 1988); Janice Radway, Reading the Romance: Women, Patriarchy and Popular Culture (Chapel Hill, 1984); Tania Modleski, Loving with a Vengeance: Mass-Produced Fantasies for Women (New York, 1982); E. Ann Kaplan, "Gender Address and the Gaze in MTV", in Rocking Around the Clock. Music Television, Postmodernism, and Consumer Culture (New York and London, 1987), pp. 89-142. Conceptually, such work 
can be used historically to excellent effect. For two examples relating to film: Patrice Petro, Joyless Streets. Women and Melodramatic Representation in Weimar Germany (Princeton, 1989); Annette Kuhn, Cinema, Censorship and Sexuality, 1909-1925 (London, 1990). For an example of an older genre, excellent of its kind, which treats film exegetically as a source of social commentary, but. from which both: women as such and the new cultural theory are absent, see Peter Stead, Film and the Working Class. The Feature Film in British and American Society (London, 1989). Stead's book falls recognizably within the 1960s/70s problematic of left-inclined British social history, doubly constituted by the influence of The Making of the English Working Class and Culture and Society, with all its virtues and limitations, which include the by-now familiar innocence on questions of gender. Historical explorations of the newer cultural perspectives can still be found most frequently in film journals such as Screen (1959--) and Jump Cut (1974--). For an important critique, which brings current perspectives to bear on the culturalist tradition deriving from Thompson and Williams' early works, see Julia Swindells and Lisa Jardine, What's Left? Women in Culture and the Labour Movement (London, 1990).

33. See in particular: Renate Bridenthal, Atine.Grossmann, and Marion Kaplan (eds.), When Biology became Destiny. Women in Weimar and Nazi Germany (New York, 1984); and Maria-Antonietta Macciocchi, "Female Sexuality in Fascist Ideology", together with Jane Caplan's Introduction, Feminist Review, 1 (1979), pp. 67-82, 59-66. Klaus Theweleit's extraordinary Male Fantasies,. 2 vols. (Minneapolis, 1987, 1988), is an indispensible starting point. For a good way-in to current work. on masculinity, see Rowena Chapman and Jonathan Rutherford (eds.), Male Order. Unwrapping Masculinity (London, 1988), and the review essays by John Tosh, Michael Roper and Joseph Bristow, HWJ, 29 (Spring 1990), pp. 184-93. Homi K. Bhabha (ed.), Nation and Narration (London, 1990), is disappointing on the gender front.

34. A good example of the continuous reduction of family history to the technical and procedural parameters of a demographic problematic, however compelling those imperatives may be in their own terms, see the response of Houston and Smith to Chaytor's dissenting article: Miranda Chaytor, "Household and Kinship: Ryton in the Late Sixteenth and Early Seventeenth Centuries", HWJ, 10 (Autumn 1980), pp. 25-60; Rab Houston and Richard Smith, "A New Approach to Family History?", HWJ, 14 (Autumn 1982), pp. 120-31. For suggestive indications of how recent theory might allow the project of the history of the family to be (de/re)constructed, see Michèle Barrett and Mary McIntosh, The Anti-Social Family (London, 1982), and Denise Riley, War in the Nursery. Theories of the Child and Mother (London, 1983). Barrett and McIntosh provide a useful critique of an influential post-Foucauldian text, Jacques Donzelot, The Policing of Families (New York, 1979): Anti-Social Family, pp. 95-105.

35. The phrase is taken from Joan Scott's already-seminal essay, "Gender: A Useful Category of Historical Analysis", in Gender and the Politics of History, pp. 28-50. The new journal, Gender and History (1989--), will be very important in this respect.

36. The first of Foucault's works to be translated was Modness and Civilization. A History of Insanity in the Age of Reason (New York, 1965), followed by The Order of Things. An Archaeology of the Human Sciences (London, 1970), 
and The Archaeology of Knowledge (London, 1972). The other works followed with increasing rapidity, until by the end of the 1970 s all were available (apart from vols. 2 and 3 of The History of Sexuality, yet to be published in French), including three collections of interviews and essays, the best of which is Colin Gordon (ed.), Power/Knowledge: Selected Interviews and Other Writings 1972-1977 by Michel Foucault (Brighton, 1980). Quite remarkably, in retrospect, the rush of social-historical works around crime, law, and punishment in the 1970s seems to have been innocent of Foucault's influence: e.g. Douglas Hay, Peter Linebaugh and Edward P. Thompson (eds.), Albion's Fatal Tree: Crime and Society in EighteenthCentury England (London, 1975); Edward P. Thompson, Whigs and Hunters. The Origins of the Black Act (London, 1975); Victor A. C. Gatrell, Geoffrey Parker and Bruce Lenman (eds.), Crime and the Law: The Social History of Crime in Western Europe since 1500 (London, 1980); Michael Ignatieff, A Just Measure of Pain: The Penitentiary in the Industrial Revolution (London, 1978); J. S. Cockburn (ed.), Crime in England 1550-1800 (London, 1977); John Brewer and John Styles (eds.), An Ungovernable People: The English and their Law in the Seventeenth and Eighteenth Centuries (London, 1980); Victor Bailey (ed.), Policing and Punishment in NineteenthCentury Britain (London, 1981); A. P. Donajgrodzki (ed.), Social Control Control in Nineteenth-Century Britain (London, 1977). For a later collection which partially registers the intervening impact of Foucault, see Stanley Cohen and Andrew Scull (eds.), Social Control and the State. Historical and Comparative Essays (Oxford, 1983), esp. Michael Ignatieff, "State, Civil Society and Total Institutions: A Critique of Recent Social Histories of Punishment" (pp. 75-105), and David Ingleby, "Mental Health and Social Order" (pp. 141-88), the two essays that respond directly to Foucault. On the other hand, two recent collections in non-British fields, pioneering interventions in empirical terms, manage to preserve their innocence: Richard J. Evans (ed.), The German Underworld. Deviants and Outcasts in German History (London, 1988); and Francis Snyder and Douglas Hay (eds.), Labour, Law, and Crime. An Historical Perspective (London, 1987). For an early text which did register the influence of Foucault, though mainly via a more general engagement with French history and philosophy of science, notably that of Gaston Bachelard, see Keith Tribe, Land, Labour and Economic Discourse (London, 1978); and for a more recent direct response, Patricia 0'Brien, "Michel Foucault's History of Culture", in Lynn Hunt (ed.), The New Cultural History (Berkeley and Los Angeles, 1989), pp. 25-46.

37. See esp. Jeffrey Weeks, "Foucault for Historians", HWJ, 14 (Autumn 1982), pp. 106-119, while the growing recognition of Foucault's centrality may be usefully tracked through Weeks' own works: Coming Out. Homosexual Politics in Britain from the Nineteenth Century to the Present (London, 1977); Sex, Politics and Society. The Regulation of Sexuality since 1800 (London, 1981); Sexuality and its Discontents. Meanings, Myths and Modern Sexualities (London, 1985); and Sexuality (London, 1986). See also Rachel Harrison and Frank Mort, "Patriarchal Aspects of NineteenthCentury State Formation: Property Relations, Marriage and Divorce, and Sexuality", in Philip Corrigan (ed.), Capitalism, State Formation and Marxist Theory (London, 1980), pp. 79-109.

38. Recent work on the history of psychology has been particularly striking. E.g. Nikolas Rose, The Psychological Complex: Social Regulation and 
the Psychology of the Individual (London, 1985), and Governing the Soul. The Shaping of the Private Self (London, 1990); Riley, War in the Nursery; J. Henriques et al. (eds.), Changing the Subject (London, 1985); R. Walden and Valerie Walkerdine, Gender and Education: Psychology's Construction of the Feminine (Milton Keynes, 1985); Carolyn Steedman, "'The Mother Made Conscious': The Historical Development of a Primary School Pedagogy", HWJ, 20 (Autumn 1985), pp. 149-63; Roger Smith, "Does the History of Psychology have a Subject?", History of the Human Sciences, 1 (Oct. 1988), pp. 147-77; Corinne Squire, Significant Differences. Feminism in Psychology (London, 1989). See also: Jacqueline Rose, The Case of Peter Pan or the Impossibility of Children's Fiction (London, 1984); and Ian Hunter, Culture and Government. The Emergence of a Literary Education (London, 1988).

39. Robert Darnton, "Intellectual and Cultural History", in Kammen (ed.), Past :Before Us, p. 332.

40. Stuart Clark, "French Historians and Early Modern Popular Culture", P\&P, 100 (Aug. 1983), pp. 62-99; Samuel Kinser, "Annaliste Paradigm? The Geohistorical Structure of Fernand Braudel"; AHR, 86 (Feb. 1981), pp. 63-105; Gregor McLennan, "Braudel and the Annales Paradigm", in Marxism and the Methodologies of History: (London, 1981), pp. 129-51; Michael Gismondi, "The Gift of Theory': A Critique of the histoire des mentalités", SH, 10 (May 1985), pp. 211-30; Patrick Hutton, "The History of Mentalities: The New Map of Cultural History", History and Theory, 20 (1981), pp. 413-23; Roger Chartier, "Intellectual History or Socio-Cultural History? "The French Trajectories", in Dominick LaCapra and Steven L. Kaplan (eds.), Modern European Intellectual History. Reappraisals and New Perspectives (Ithaca, 1982); pp. 13-46; Dominick LaCapra, "Is Everyone a Mentalite Case? Transference and the 'Culture' Concept", in History and Criticism (Ithaca, 1985), pp. 71-94.

41. The process of contextualizing Bloch's achievement has now been eased by a new biography, Carole Fink, Marc Bloch. A Life in History (Cambridge, 1989).

42. See the discussion in section (d) below and in note 32 to section (a) above. See also Patrick Joyce (ed.), The Historical Meanings of Work (Cambridge, 1987); many of the essays in Steven L. Kaplan and Cynthia J. Koepp (eds.), Work in France. Representations, Meaning, Organization, and Practice (Ithaca, 1986); William M. Reddy, Money and Liberty in Modern Europe. A Critique of Historical Understanding (Cambridge, 1987); David Vincent, Literacy :and Popular Culture: England 1750-1914 (Cambridge, 1990); and Hunt (ed.), New Cultural History. The impact of LaCapra and the current writings of Chartier are particularly strong signs of this change: see also Lloyd S. Kramer, "Literature, Criticism, and Historical Imagination: The Literary Challenge of Hayden White and Dominick LaCapra", and Roger Chartier, "Texts, Printings, Readings", both in Hunt (ed.), New Cultural History; pp. 97-128 and 154-75. The fourway discussion in JMH among Chartier, Darnton, LaCapra, and Fernandez listed in note 18 above is also symptomatic. Interestingly, the volume edited by Peter Burke (who was one of the principal advocates of Annales history in the English-speaking world in the 1970s), Peter Burke and Roy Porter (eds.), The Social History of Language (Cambridge, 1987), falls much short of the post-structuralist understanding of language, 
with the exception of Dorinda Outram's "Le langage male de la vertu: Women and the Discourse of the French Revolution", pp. 120-35. For an overview of the turn to culture among social historians in Germany, see Geoff Eley, "Labor History, Social History, Alltagsgeschichte: Experience, Culture, and the Politics of the Everyday--A New Direction for German Social History?", JMH, 61 (June 1989), pp. 297-343.

43. See Natalie Zemon Davis, Society and Culture in Early Modern France (Stanford, 1975); Robert W. Scribner, For the Sake of Simple Folk: Popular Propaganda for the German Reformation (Cambridge, 1981), and "Reformation, Carnival, and the World Turned Upside-Down", SH, 3 (Odt. 1978), pp. 303-29. For literary appropriations of Bakhtin, see Tony Bennett, Formalism and Marxism (London, 1979), esp. pp. 75-98; Robert Stam, "Mikhail Bakhtin and Left Cultural Critique", in E. Ann Kaplan (ed.), Postmodernism and its Discontents. Theories, Practices (London, 1988), pp. 116-45; Peter Stallybrass and Allon White, The Politics and Poetics of Transgression (Ithaca, 1986).

44. André Burguière, "The Fate of the History of Mentalities in the Annales", CSSH, 24 (July 1982), pp. 424-37.

45. As well as the works cited in note 32 above, see the following: Tony Bennett, Colin Mercer and Janet Woollacott (eds.), Popular Culture and Social Relations (Milton Keynes, 1986); Colin MacCabe (ed.), High Theory/Low Culture. Analyzing Popular Television and Film (Manchester, 1986); Tony Bennett, Susan Boyd-Bowman, Colin Mercer, and Janet Woollacott (eds.), Popular Television and Film (London, 1981); Alan Tomlinson (ed.), Consumption, Identity, and Style. Marketing, Meanings, and the Packaging of Pleasure (London, 1990); Robert C. Allen (ed.), Channels of Discourse. Television and Contemporary Criticism (Chapel Hill, 1987); Helen Baehr and Gillian Dyer (eds.), Boxed In: Women and Television (London, 1987); Simon Frith and Andrew Goodwin (eds.), On Record. Rock, Pop, and the Written Word (New York, 1990); Judith Williamson, Decoding Advertisements. Ideology and Meaning in Advertising (London, 1978); A. L. Rees and Frances Borzello (eds.), The New Art History (Atlantic Highlands, N.J., 1988); Griselda Pollock, Vision and Difference. Femininity, Feminism and the Histories of Art London, 1988); James Donald (ed.), Fantasy and the Cinema (London, 1989); Stuart Laing, Representations of Working-Class Life 1957-1964 (London, 1986); John Hill, Sex, Class and Realism. British Cinema 1956-1963 (London, 1986); Martin Barker, A Haunt of Fears. The Strange History of the British Horror Comics Campaign (London, 1984); Ken Worpole, Dockers and Detectives. Popular Reading: Popular Writing (London, 1983); Michael Denning, Mechanic Accents. Dime Novels and Working-Class Culture in America (1987); Helen Carr (ed.), From My Guy to Sci-Fi: Genre and Women's Writing in the Postmodern World (London, 1989); Susannah Radstene (ed.), Sweet Dreams. Sexuality, Gender and Popular Fiction (London, 1988); Carolyn Kay Steedman, Landscape for a Good Woman. A Story of Two Lives (London, 1986); Peter Widdowson (ed.), Re-reading English (London, 1982); Janet Batsleer, Tony Davies, Rebecca O'Rourke, and Chris Weedon, Rewriting English. Cultural Politics of Gender and Class (London, 1985); Centre for Contemporary Cultural Studies (ed.), The Empire Strikes Back. Race and Racism in 70s Britain (London, 1982); Francis Barker et al. (eds.), Europe and its Others, vol. 1 (Colchester, 1985); Timothy Brennan, Salman Rushdie and the Third World New York, 1989); Dale Carter, The Final-Frontier. The Rise and Fall of the American Rocket State (London, 
1988); Duncan Webster, Looka Yonder! The Imaginary America of Populist Culture (London, 1988). Introduction to the overall field of cultural studies may now be had from the following: David Punter (ed.), Introduction to Contemporary Cultural Studies (London, 1986); Michael Gurevitch, Tony Bennett, James Curran, and Janet Woollacott (eds.), Culture, Society and the Media (London, 1982); Stuart Hall, Dorothy Hobson, Andrew Lowe, and Paul Willis (eds.), Culture, Media, Language (London, 1980); Fred Inglis, Media Theory: An Introduction (Oxford, 1990); Peter Jackson, Maps of Meaning. An Introduction to Cultural Geography (London, 1989); Ian Angus and Sut Jhally (eds.), Cultural Politics in Contemporary America (New York, 1989); Patrick Brantlinger, Crusoe's Footprints. Cultural Studies in Britain and America (New York, 1990).

46. Popular Memory Group, "Popular Memory: Theory, Politics, Method", and Michael Bommes and Patrick Wright, "'Charms of Residence': The Public and the Past", in Richard Johnson; Gregor McLennan, Bill Schwarz, and David Sutton (eds.), Making Histories. Studies in History-Writing and Politics (London, 1982); pp. 205-52 and 253-301; Robert Colls and Philip Dodd (eds.), Englishness. Politics and Culture 1880-1920 (London, 1986); Patrick Wright, On Living in an 0ld Country. The National Past in Contemporary Britain (London, 1985); Robert Hewison, The Heritage Industry. Britain in a Climate of Decline (London, 1987); Robert Lumley (ed.), The Museum Time Machine. Putting Cultures on Display (London, 1988); Roger Bromley, Lost Narratives. Popular Fictions, Politics and Recent History (London, 1988); Alan Sinfield, Literature, Politics, and Culture in Postwar Britain (Berkeley and Los Angeles, 1989); Formations of Nation and People (London, 1984); Raphael Samuel (ed.), Patriotism: The Making and Unmaking of British National Identity, 3 vols. (London, 1989); Lutz Niethammer (ed.), Lebensgeschichte und Sozialkultur im Ruhrgebiet 1930 bis 1960, 3 vols. (Bonn, 1983, 1983, 1986); Luisa Passerini, Fascism in Popular Memory. The Cultural Experience of the Turin Working Class (Cambridge, 1987); Bhabha (ed.), Nation and Narration.

47. Geoff Eley, "Some Recent Tendencies in Social History", in Georg G. Iggers and Harold T. Parker (eds.), International Handbook of Historical Studies. Contemporary Research and Theory (Westport, CT, 1979), p. $55 f$.

48. Charles Tilly and Immanuel Wallerstein remain the tireless exemplars of such work. For their most recent contributions, see Tilly, Coercion, Capital, and European States, AD 990-1990 (Oxford, 1990); Wallerstein, The Modern World-System III: The Second Era of Great Expansion of the Capitalist World-Economy (New York, 1988).

49. See Anthony Giddens, A Contemporary Critique of Historical Materialism, vol. 1: Power, Property and the State (London, 1981), and The Nation-State and Violence, vol. 2 of A Contemporary Critique of Historical Materialism (Cambridge, 1985); Michael Mann, The Sources of Social Power, I: A History of Power from the Beginning to AD 1760 (Cambridge, 1986); John A. Hall, Powers and Liberties. The Causes and Consequences of the Rise of the West (0xford, 1985). There is an excellent critical summary of this genre in Perry Anderson, "A Culture in Contraflow--I", NLR, 180 (March-April 1990), pp. 41-78, where he adds the work of $W$. $G$. Runciman, Ernest Gellner, and Jack Goody. Of course, Anderson is himself in the midst of such a global history: Passages from Antiquity to Feudalism, and Lineages of the Absolutist State (London, 1974). 
50. Hayden White, Metahistory: The Historical Imagination in Nineteenth-Century Europe (Baltimore, 1973), and Tropics of Discourse: Essays in Cultural Criticism (Baltimore, 1978).

51. Editorial, "Language and History", HWJ, 10 (Autumn 1980), p. 1. Of course, we shouldn't concentrate too much responsibility for this basic move in Derrida and De Man. "Reading texts for their silences" was a commonplace of British Althusserian Marxism in the mid-1970s.

52. Jacques Derrida, "Like the Sound of the Sea Deep within a Shell: Paul De Man's War", Critical Inquiry, 14 (Spring 1988), p. 606.

53. Tony Bennett, "Text and History", in Widdowson (ed.), Re-Reading English, p. 235.

54. E.g. Clifford Geertz, "Ideology as a Cultural System", in The Interpretation of Cultures (New York, 1973), pp. 208ff., and "Deep Play: Notes on a Balinese Cockfight", ibid., pp. 449-53.

55. The works cited by Raymond Williams are: Culture and Society 1780-1950 (London, 1958); The Long Revolution (London, 1961); "Base and Superstructure in Marxist Cultural Theory", NLR, 82 (Nov.-Dec. 1973), pp. 77-91; Marxism and Literature (Oxford, 1977). Many more particular references could be given from Williams' voluminous bibliography. "Literature and Sociology: In Memory of Lucien Goldmann", NLR; 67 (May-June 1971), pp. 3-18, was an earlier engagement with continental literary theory; "Marxism, Structuralism and Literary Analysis", NLR, 129 (Sept.-Oct. 1981), pp. 51-66, surveys the sequence of influences listed above; "The Uses of Cultural Theory", NLR, 158 (July-Aug. 1986), pp. 19-31, focuses on the specific legacy of the Vitebsk school of Soviet linguistic theorists from the 1920s (P. M. Medvedev, V. N. Volosinov, M. M. Bakhtin). "When Was Modernism?", NLR, 175 (May-June 1989), pp. 48-52, was reconstructed by Fred Inglis from lecture notes; the verdict attributed to Williams on postmodernism--"Postmodernism for him was a strictly ideological compound from an enemy formation, and long in need of this authoritative rebuttal" ( $p .48)$--doesn't at all characterize the text itself, which is silent on postmodernism per se, and shouldn't be allowed to stand.

56. This complicated intellectual history may be tracked through the following: Stuart Hall, "Cultural Studies and the Centre: Some Problematics and Problems", in Hall et al. (eds.), Culture, Media, Language, pp. 15-47; Ted Benton, The Rise and Fall of Structural Marxism. Althusser and his Influence (London, 1984); Gregory Elliott,. Althusser: The Detour of Theory (London, 1987); Terry Lovell (ed.), British Feminist Thought: A Reader (Oxford, 1990); Geoff Eley, "Reading Gramsci in English: Observations on the Reception of Antonio Gramsci in the English-Speaking World, 1957-82", European History Quarterly, 14 (Oct. 1984), pp. 441-78; David Forgacs, "Gramsci and Marxism in Britain", NLR, 176 (July-Aug. 1989), pp. 70-88; Perry Anderson, In the Tracks of Historical Materialism (London, 1983).

57. Lovell, Introduction to "Feminism and the Historians", in Lovell (ed.), British Feminist Thought, p. $21 \mathrm{f}$. 
58. Alexander, "Women, Class and Sexual Differences", p.127. The same passage is quoted by Lovell in the same Introduction, British Feminist Thought, p. 25 (where the Alexander essay is also reprinted, pp. 28-50), and by Swindells and Jardine, What's Left?, p. 93. I've always thought there's a kind of presumption in male historians trying to speak for women's history; yet the alternative of more incidental forms of reference can't escape the effect of tokenism. There's no easy solution. For some useful thoughts, see Janet Todd, "Men in Feminist Criticism", in Feminist Literary Theory (London, 1988), pp. 118-34, which reflects on such discussions in the literary realm.

59. See Ellen Meiksins Wood, The Retreat from Class. A New "True" Socialism (London, 1986).

60. Jean-Francois Lyotard, The 'Post-Modern Condition (Minneapolis, 1984), p. Xiiif.; Kate Ellis, "Stories without Endings: Deconstructive Theory and Political Practice", Socialist Review, 19 (1989), p. 38.

61. The phrases are quoted from the editorial essay, "Psychology, Ideology and the Human Subject", in the first issue of Ideology and Consciousness, 1 (Summer 1977), p. , by Stuart Hall in his critique of the editorial, "Some Problems with the Ideology/Subject Couplet", Ideology and Consciousness, 3 (Spring 1978), p. 120.

62. Scott, Gender and the Politics of History, p. 4.

63. Paul Q. Hirst, "Interview with Local Consumption", in Marxism and Historical Writing (London, 1985), p. 138.

64. Paul Q. Hirst, "Collingwood, Relativism and the Purposès of History", ibid., p. 54 .

65. Stedman Jones, "From Historical Sociology", pp. 296, 297.

66. Paul Q. Hirst, "Anderson's Balance Sheet", in Marxism and Historical Writing, p. 28. Hirst's essays, mostly produced between the late-1970s and early-1980s, are a useful guide through these questions. See also the following comment in "On Ideology", in Hirst, On Law and Ideology (London, 1979), p. 21: "We would argue that discourses and practices do employ the criteria of appropriateness or adequacy (not of epistemological validity) but these are specific to the objectives of definite bodies of discourse and practice. None will pass muster as a general criterion of validity, but there is no knowledge process in general and, therefore, no necessity for such a criterion. Techniques of criticism of biblical texts are of no use in garage mechanics. Questions of priority and relation in the Gospels, of the state of wear of a gearbox elicit different types of tests and disputes about them. The referents and constructs, Gospels, motor cars, depend on conditions which differ, so do criteria and tests. Tests, etc., develop within the discourses and practices to which they relate and are subject to dispute. As tests they are radically different, they seek to establish or challenge different things according to the objectives and circumstances of the practice in question".

67. Whereas this approach derives strongly from Foucault, it also has affinities with the "keywords" method of Raymond Williams and with the work of Reinhart Koselleck and the West German tradition of Begriffsgeschichte. See Williams, 
Keywords: A Vocabulary of Culture and Society (2nd ed., London, 1983); Otto Brunner, Werner Conze, and Reinhart Koselleck (eds.), Geschichtliche Grundbegriffe, 5 vols. (Stuttgart, 1972-1989). For an excellent brief introduction to the latter, see Keith Tribe, "The Geschichtliche Grundbegriffe Project: From History of Ideas to Conceptual History", CSSH, 31 (Jan. 1989), pp. 180-84.

68. Michel Foucault, "Body/Power", in Gordon (ed.), Power/Knowledge, p. 60.

69. Michel Foucault, "The Politics of Health in the Eighteenth Century", ibid., p. 176.

70. In addition to the works cited in notes 37 and 38 above, see also: Donzelot, Policing of Families; Frank Mort, Dangerous Sexualities: Medico-Moral Politics in England since 1830 (London, 1987); Antony Copley, Sexual Moralities in France, 1780-1980. New Ideas on the Family, Divorce, and Homosexuality. An Essay on Moral Change (London, 1989).

71. Robert Gray, "The Deconstruction of the English Working Class", SH, 11 (Oct. 1986), p. 367.

72. Alexander, "Women, Class and Sexual Differences", p. 137.

73. The phrase was used by Chantal Mouffe in a CSST lecture, "Rethinking Pluralism", University of Michigan, 21 Sept. 1989.

74. Landes, Women and the Public Sphere, p. 204.

75. Ibid., p. 46 .

76. John Keane, Introduction, in Keane (ed.), Civil Society and the State. New European Perspectives (London, 1988), p. 21.

77. Hall, "Private Persons versus Public Someones", p. 11.

78. E.g. the works cited in note 29 above.

79. Bryan D. Palmer, Descent into Discourse. The Reification of Language and the Writing of Social History (Philadelphia, 1990), p. 188.

80. Ibid., p. 199. 
PROGRAM ON THE

COMPARATIVE STUDY OF SOCIAL TRANSFORMATIONS

UNIVERSITY OF MICHIGAN

WORKING PAPER SBRIES

The Program on the Comparative Study of Social Transformations is an interdisciplinary research program at the University of Michigan. Its faculty associates are drawn primarily from the departments of Anthropology, History, and Sociology, but also include members of several other programs in the humanities and social sciences. Its mission is to stimulate new interdisciplinary thinking and research about all kinds of social transformations in a wide range of present and past societies. CSST Working Papers report current research by faculty and graduate student associates of the program. Many will be published elsewhere after revision. Working Papers are available for a fee of $\$ 2.00$ for papers under 40 pages and for $\$ 3.00$ for longer papers. To request copies of Working Papers, write to The Program on the Comparative Study of Social Transformations (CSST), 4010 LSA Building, University of Michigan, Ann Arbor, MI 48109-1382 or call (313) 936-1595. The CSST working paper series is a part of the Center for Research on Social Organizations' working paper series. CRSO numbers are noted.

1. "Program in Comparative Study of Social Transformations," William Sewell, Terrence McDonald, Sherry Ortner, and Jeffery Paige, May $87,15 \mathrm{pp}$. (CRSO \#344)

2. "Labor History, Uneven Development, and the Autonomy of Politics: The Dockworkers of Nineteenth-Century Marseille," William Sewell, Jul 87, 45 pp. (CRSO \#346) (Now in print as "Uneven Development, the Autonomy of Politics and the Dockworkers of Nineteenth-Century Marseille," American Historical Review 93:3 (Jun 88), pp. 604-37.)

3. "Coffee, Copper, and Class Conflict in Central America and Chile: A Critique of Zeitlin's Civil Wars in Chile and Zeitlin and Ratcliff's Landlords and Capitalists," Jeffery Paige, Sep 87, $10 \mathrm{pp}$. (CRSO \#347)

4. "In Search of the Bourgeois Revolution: The Particularities of German History," Geoffrey Bley, Sep 87,61 pp. (CRSO *350)

5. "The Burdens of Urban History: The Theory of the State in Recent American Social History," Terrence McDonald, May 88, $50 \mathrm{pp}$. (CRSO \#355)

6. "History, Sociology, and Theories of Organization," Mayer Zald, May 88, 42 pp. (CRSO \#357)

7. "Have Social Historians Lost the Civil War? Some Preliminary Demographic Speculations," Maris Vinovskis, May 88, 55 pp. (CRSO \#358) 
8. "Revolution and the Agrarian Bourgeoisie in Nicaragua," Jeffery Paige, 42 pp. (CRSO \#363)

9. "Nationalism and Class as Factors in the Revolution of 1917," Ronald Suny, Oct $88,42 \mathrm{pp}$. (CRSO \#365)

10. "The Original Caste: Power, History, and Hierarchy in South Asia," Nicholas Dirks, Oct 88, 30 pp. (CRSO \#367)

11. "The Invention of Caste: Civil Society in Colonial India," Nicholas Dirks, Oct $88,24 \mathrm{pp}$. (CRSO $\# 368$ )

12. "Sociology as a Discipline: Quasi-Science and Quasi-Humanities," Mayer Zald, Oct $88,43 \mathrm{pp}$. (CRSO $* 369$ )

13. "Constraints on Professional Power in Soviet-Type Society: Insights from the Solidarity Period in Poland," Michael Rennedy and Konrad Sadkowski, Nov 88, 37 pp. (CRSO \#371)

14. "Evolutionary Changes in Chinese Culture," Martin Whyte, Nov 88, 20 pp. (CRSO \#372)

15. "World Market, Class Conflict, and Rural Coercion in Post-Colonial Buenos Aires," Karl Monsma, Nov 88, 22 pp. (CRSO \#373)

16. "Ritual and Resistance: Subversion as a Soclal Fact," Nicholas Dirks, Dec 88, $39 \mathrm{pp}$. (CRSO \#375)

17. "Social Transformations of Gender in Andean South America: A Working Annotated Bibliography," Janise Hurtig, Dec 88, 24 pp. (CRSO \#376)

18. "Labour History--Social History--Alltagsgeschichte: Experience, Culture, and the Politics of the Everyday. A New Direction for German Social History?" Geoff Eley, Jan 89, $85 \mathrm{pp.} \mathrm{(CRSO}$ \#378. (Now in print in Journal of Modern History 61 (Jun 89), ppp. 297-343.)

19. "Notes on the Sociology of Medical Discourse: The Language of Case Presentation," Renee Anspach, Jan 89, 32 pp. (CRSO \#379)

20. "World War Two and the Deradicalization of American Labor: A 'Deviant Case' Study," Howard Kineldorf, Feb 89, 45 pp. (CRSO \#383)

21. "Taking Stock: The First Year of CSST," Geoff Eley, Feb 89, 7 pp. (CRSO \#384)

22. "Immigration Research: A Conceptual Map," Silvia Pedraza-Bailey, Feb $89,15 \mathrm{pp}$. (CRSO \#385)

23. "Culture/Power/History. Series Prospectus," Sherry Ortner, Nicholas Dirks, and Geoff Eley, Mar 89, 4 pp. (CRSO \#386) 
24. "A Feminist Perspective on Christopher Lasch, 'The Social Invasion of the Self'," Sherry Ortner, Apr 89,6 pp. (CRSO \$387)

25. "Does Rational Choice Have Utility on the Margins?" Akos Rona-Tas, Apr $89,31 \mathrm{pp}$. (CRSO \#388)

26. Research Fellows Conference Panel on "The Politics of Social Transformation," Seong Nae Rin, Joanne Goodwin, Kathleen Canning, Jun 89. (CRSO \#389)

27. Research Fellows Conference Panel on "Struggle, Conflict, and Constraints on Social Change," Anne Gorsuch and Sharon Reitman, Jun 89. (CRSO $\$ 390)$

28. Research Fellows Conference Panel on "Subordinate Actors and their Marginalization in Social Theory," Nilufer Isvan, Akos RonaTas, Cynthia Buckley, Theresa Deussen, and Mayfair Yang, Jun 89. (CRSO \#391)

29. "Toward a Theory of Structure: Duality, Agency, and Transformation," William Sevell, Jun 89, 56 pp. (CRSO \#392)

30. "The Power of Individual Subjectivity and the Subjectivity of Power in Education," Peter Appelbaum, Jul 89,40 pp. (CRSO \#396)

31. "Family Ideology, Class Reproduction, and the Suppression of Obscenity in Nineteenth Century New York," Nicola Beisel, Jul 89, 29 pp. (CRSO \#397)

32. "Author Meets Critics: Reactions to "Theory and Anthropology since the Sixties," Sherry Ortner, ed., Aug 89. (CRSO \#398)

33. :"Does Social Theory Need History? Reflections on Epistemological Encounters in the Social Sciences," Margaret Somers, Aug 89, $23 \mathrm{pp}$. (CRSO \#399)

34. "Gender, History and Deconstruction: Joan Wallach Scott's Gender And The Politics of History," William Sewell, Aug 89, 20 pp. (CRSO \#400)

35. "The Social Origins of Dictatorship, Democracy and Socialist Revolution in Central America," Jeffery Paige, Sep 89, 12 pp. (CRSO \#405)

36. "Max Weber Meets Feminism: A Reconstruction of Charisma," Cheryl Hyde, Sep 89, 24 pp. (CRSO \$407)

37. "Understanding Strikes In Revolutinary Russia," William Rosenberg, Sep 89,36 pp. (CRSO \#408)

38. "Child Labor Laws: A Historical Case of Public Policy Implementation," Marjorie McCall-Sarbaugh and Mayer Zald, Oct 89, 41 pp. (CRSO \#409) 
39. "Putting German (and Britian) Liberalism into Context: Liberalism, Europe, and the Burgeoisie, 1840-1914," Geoff Eley, Nov 89, $39 \mathrm{pp}$. (CRSO \#411)

40. "Bringing Unjons Back In (Or, Why we Need A New Old Labor History)," Howard Kimeldorf, Feb 90, 13 pp. (CRSO \#414)

41. "In Flight From Politics: Social History And Its Discontents," David Mayfield and Susan Thorne, Feb 90,32 pp. (CRSO \#415)

42. Nations, Politics, and Political Cultures: Placing Habermas in the Nineteenth Century," Geoff Eley, Apr 90, 34 pp. (CRSO \#417)

43. "Reviewing The Socialist Tradition," Geoff Eley, Apr 90, 29 pp. (CRSO \#418)

44. "Rethinking Labor History: Toward a Post-Materialist Rhetoric," William Sewell, May 90, 20 pp. (CRSO \#421)

45. "The Intelligentsia in the Constitution of Civil Societies and Post Communist Regimes in Hungary and Poland," Michael Kennedy, Jul 90, 51 pp. (CRSO \#425)

46. "The Constitution of Critical Intellectuals: Polish Physicians, Peace Activists and Democratic Civil Society," Michael Kennedy, Apr $90,38 \mathrm{pp}$. (CRSO \#419)

47. "Dominant $\mathrm{Class}$ and Statemaking in a Peripheral Area: Argentina after Independence," Karl Monsma, Aug 90, 50 pp. . (CRSO \#429)

48. "Eastern Europe's Lessons for Critical Intellectuals," Michael Kennedy, Aug 90,26 pp. (CRSO \#430)

49. "The Alternative in Eastern Europe at Century's Start: Brzozowski and Machajski on Intellectuals and Socialism," Michael Kennedy. Aug $90,21 \mathrm{pp}$. (CRSO \#431)

50. "Collective Violence and Collective Loyalties in France: why the French Revolution Made a Difference," William Sewell, Aug 90, $37 \mathrm{pp}$. (CRSO \#432)

51. "Transformations of Normative Foundations and Empirical Sociologies: Class, Stratification and Democracy in Poland," Michael. Kennedy, Sep 90,39 pp. (CRSO $* 433$ )

52. "What We Talk About When We Talk About History: The Conversations of History and Sociology," Terrence McDonald, Oct 90, 27 pp. (CRSO \#442)

53. "Is Vice Versa? Historical Anthropologies and Anthropological Histories," Nicholas Dirks, Oct 90, 27 pp. (CRSO \#443) 
54. "Narrativity, Culture, and Causality: Toward a New Historical Epistemology or Where is Sociology After the Historic Turn?" Margaret Somers, Oct 90, 26 pp. (CRSO \#444)

55. "Is All the World a Text? From Soclology History to the History of Society Two Decades Later," Geoff Eley, Oct 90, 23 pp. (CRSO \#445)

56. "Who Shapes the Text?: Sherpas and Sahibs on Mount Everest," Sherry Ortner, Oct $90,19 \mathrm{pp}$. (CRSO $\$ 446$ )

57. "What Social Theory. Needs from History Now: Culture and Action as Problems for Historical Sociology," Craig Calhoun, Oct 90, 19 pp. (CRSO \#447)

58. "Three Temporalities: Toward a Sociology of the Event," William Sewell, Oct $90,24 \mathrm{pp}$. (CRSO \#448)

59. "The New Non-Science of Politics: On Turns to History in Political Science," Rogers Smith, Oct 90, 28 pp. (CRSO \#449)

60. "Feeling History: Reflections on the Western Culture Controversy," Renato Rosaldo, Oct $90,7 \mathrm{pp.}$ (CRSO \#450)

61. "Historicizing 'Experience'," Joan Scott, Oct 90, 19 pp. (CRSO \#451)

62. "The Past as Authority and as Social Critic: Stabilizing and Destabilizing Functions of History in Legal Argument," Robert Gordon, Oct 90,26 pp. (CRSO \#452)

63. "Discursive Forums, Cultural Practices: History and Anthropology in Literary Studies," Steven Mullaney, Oct 90, $17 \mathrm{pp}$. (CRSO \#453)

64. "Sexual Affronts and Racial Frontiers: National Identity, 'Mixed Bloods' and the Cultural Genealogies of Europeans in Colonial Southeast Asia," Ann Stoler, May 91, 60 pp. (CRSO \#454)

65. "Cracking the Code Allegory and Political Mobilization in the Greek Resistance," Janet Hart, June 91, 48 pp. (CRSO \#455) 